\title{
The difference between Asian and Western in the effect of LDL-C lowering therapy on coronary atherosclerotic plaque: a meta-analysis report
}

\author{
Yu-Feng $\mathrm{Li}^{1 \dagger}$, Quan-Zhou Feng ${ }^{1 *+}$, Wen-Qian Gao ${ }^{2 \dagger}$, Xiu-Jing Zhang ${ }^{3 \dagger}$, Ya Huang ${ }^{1}$ and Yun-Dai Chen ${ }^{1 *}$
}

\begin{abstract}
Background: The different effects of LDL-C levels and statins therapy on coronary atherosclerotic plaque between Western and Asian remain to be settled.

Methods: PubMed, EMBASE, and Cochrane databases were searched from Jan. 2000 to Sep. 2014 for randomized controlled or blinded end-points trials assessing the effects of LDL-C lowering therapy on regression of coronary atherosclerotic plaque (CAP) in patients with coronary heart disease by intravascular ultrasound. The significance of plaques regression was assessed by computing standardized mean difference (SMD) of the volume of CAP between the baseline and follow-up.

Results: Twenty trials (ten in the West and ten in Asia) were identified. For Westerns, Mean lowering LDL-C by $49.4 \%$ and/or to level $61.9 \mathrm{mg} / \mathrm{dL}$ in the group of patients with baseline mean LDL-C $123.2 \mathrm{mg} / \mathrm{dL}$ could significantly reduce the volume of CAP at follow up (SMD $\left.-0.156 \mathrm{~mm}^{3}, 95 \% \mathrm{Cl}-0.248 \sim-0.064, p=0.001\right)$. LDL-C lowering by rosuvastatin (mean $40 \mathrm{mg}$ daily) could significantly decrease the volumes of CAP at follow up. For Asians, Mean lowering LDL-C by $36.1 \%$ and/or to level $84.0 \mathrm{mg} / \mathrm{dL}$ with baseline mean LDL-C $134.2 \mathrm{mg} / \mathrm{dL}$ could significantly reduce the volume of CAP at follow up (SMD $\left.-0.211 \mathrm{~mm}^{3}, 95 \% \mathrm{Cl}-0.331 \sim-0.092, p=0.001\right)$. LDL-C lowering by rosuvastatin (mean $14.1 \mathrm{mg}$ daily) and atorvastatin (mean $18.9 \mathrm{mg}$ daily) could significantly decrease the volumes of CAP at follow up.

Conclusions: There was a different effect of LDL-C lowering on CAP between Westerns and Asians. For regressing CAP, Asians need lower dosage of statins or lower intensity LDL-C lowering therapy than Westerns.
\end{abstract}

Keywords: Low-density lipoprotein-cholesterol, Coronary atherosclerotic plaque, Intravascular ultrasound, Coronary artery disease, Western, Asian

\section{Background}

Atherosclerotic plaque is the hallmark and cornerstone of atherosclerotic disease. Disruption of coronary atherosclerotic plaque (CAP) may lead to sudden cardiac death, acute myocardial infarction, or unstable angina [1]. Intravascular ultrasound (IVUS) is considered to be gold standard for measurement of atherosclerotic plaque [2].

The meta-analysis of twenty trials evaluated the effects of LDL-C lowering on CAP indicated that intensive LDL-C lowering with statins could slow atherosclerotic plaque progression and lead to plaque regression [3].

\footnotetext{
* Correspondence: fqz301@yahoo.com; cyundai@medmail.com.cn

${ }^{\dagger}$ Equal contributors

${ }^{1}$ The Department of Cardiology, Chinese PLA General Hospital, Fuxing Road 28, Beijing 100853, China

Full list of author information is available at the end of the article
}

But the meta-analysis did not investigate the effects of LDL-C lowering on CAP in different race.

In this meta-analysis, we investigated the difference between Western and Asian in the effect of LDL-C lowering therapy on the progression of the CAP from the current trials on LDL-C lowering therapy retarding the progression of the CAP and identified the different targets of LDL-C that result in the regression of the CAP for Western and Asian.

\section{Methods}

Materials and methods of this meta-analysis were detailed in the paper by Gao et al. [3].

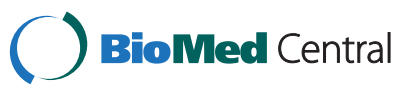

(c) 2015 Li et al.; licensee BioMed Central. This is an Open Access article distributed under the terms of the Creative Commons Attribution License (http://creativecommons.org/licenses/by/4.0), which permits unrestricted use, distribution, and reproduction in any medium, provided the original work is properly credited. The Creative Commons Public Domain Dedication waiver (http://creativecommons.org/publicdomain/zero/1.0/) applies to the data made available in this article unless otherwise stated. 


\section{Search strategy and selection criteria}

An electronic literature search was performed to identify all relevant studies published in PubMed, EMBASE, and Cochrane databases in the English language from Jan. 1, 2000 to Sep. 13, 2014, using the terms "atherosclerosis" and "cholesterol blood level". Trials were included using the criteria as: 1) randomized controlled or prospective, blinded end-points trials, and its primary end point was CAP change detected by IVUS; 2 ) report of LDL-C levels at baseline and follow-up; 3) data on the volume of CAP at baseline and follow-up, and volume of CAP was calculated as vessel volume minus lumen volume; Exclusion criteria were: 1) only CAP area or volume index or percent atheroma volume were detected; 2) the levels of LDL-C at baseline or follow-up were not provided; and 3) target plaques were unstable.

\section{Data extraction and quality assessment}

Two investigators independently reviewed all potentially eligible studies and collected data on patient and study characteristics, and any disagreement was resolved by consensus. The primary end point of this study was the volume change of CAP detected by IVUS. Quality assessments of trials were evaluated with Jadad quality scale.

\section{Data synthesis and analysis}

Volume changes of CAP from baseline to follow-up were analyzed using standardized mean differences (SMD).

Volume changes of plaque in every arm were used for pooled analysis. The trials were firstly grouped into group Western and Asian according to the location of the trials. Then, according to the levels and the reducing percentage of LDL-C at follow-up, the arms were grouped to following groups: $\leq 70,>70 \leq$ $100 \mathrm{HP},>70 \leq 100 \mathrm{MP},>70 \leq 100 \mathrm{LP},>100 \mathrm{mg} / \mathrm{dL}$; and $<0, \geq 0<30, \geq 30<40, \geq 40<50, \geq 50 \%$ respectively [3], to investigate the effect of different levels of LDL-C at follow up on CAPs. According to statins, the arms were grouped to: rosuvastatin, atorvastatin, pitavastatin, simvastatin, fluvastatin and pravastatin groups, to investigate the effect of different statins on CAPs. The volume of CAP at follow up was compared with that at baseline to evaluate effect of LDL-C levels on regression of CAP.

Heterogeneity across trials (arms) was assessed via a standard $\chi^{2}$ test with significance being set at $p<0.10$ and also assessed by means of $I^{2}$ statistic with significance being set at $I^{2}>50 \%$. Pooled analyses were calculated using fixed-effect models, whereas random-effect models were applied in case of significant heterogeneity across trials (arms). Sensitivity analyses (exclusion of one study at one time) were performed to determine the stability of the results. Publication bias was assessed using the
Egger regression asymmetry test. Statistical analyses were performed using STATA software 12.0 (StataCorp, College Station, Texas).

All continuous variables were expressed as mean \pm SD, and continuous variables were compared between the Western and Asian groups using Student's t test (SigmaStat 3.5). A P value $<0.05$ was considered to be statistically significant.

\section{Results \\ Eligible studies}

The flow of selecting studies for the meta-analysis was shown in Figure 1. Briefly, of the initial 673 articles, one hundred and twenty-two of abstracts were reviewed, resulting in exclusion of 102 articles, and 20 articles were reviewed in full text, resulting in exclusion of 10 trials and inclusion of 18 additional trials cited in the 20 articles. Twenty two RCTs [4-25] and six blinded end-points trial [26-31] were carefully evaluated, and eight trials $[4,8,9,18,19,21,27,31]$ were excluded because of specific the index of plaque or lack of some data. Sixteen RCT (ESTABLISH [11], REVERSAL [10], A-PLUS [5], ACTIVATE [6], ILLUSTRATE [7], JAPAN-ACS [20], REACH [14], SATURN [16], ARTMAP [17], ERASE [23], STRADIVARIUS [24], PERISCOPE [25], and trials by Yokoyama M [12], by Kawasaki M [13], by Hong MK [15], and Tani S [22]) and four blinded end-points trial (ASTEROID [26], COSMOS [29], trial by Jensen $\mathrm{LO}$ [28] and trial by Nasu K [30]) were finally analyzed.

The characteristics of the included trials were as same as in the study [3] and shown in Table 1. Briefly, among the 20 trials, 10 trials are completed in European, America and Australia [10,5-7,16,23-26,28], 10 in Asia [20,11-15,17,22,29,30], and there were 15 trials assessing statins (statin vs. usual care in 6 trials [11-14,22,30]; intensive statin vs. moderate statin treatment in 5 trials $[10,15-17,20]$; follow up vs baseline in 3 trial $[26,28,29]$, before acute coronary syndrome (ACS) vs after ACS in one trial [23]), 2 trials assessing enzyme acyl-coenzyme A: cholesterol acyltransferase (ACAT) inhibition [5,6], one trial assessing cholesteryl ester transfer protein (CETP) inhibitor torcetrapib [7], one trial assessing a decreasing obesity drug: rimonabant [24], and one trial assessing glucose-lowering agents [25]. Overall, 5910 patients with coronary heart disease (CHD) underwent serial IVUS examination for evaluating regression of CAP. Follow-up periods ranged from 2 to 24 months. The levels of LDL-C of each arm at baseline and follow-up were shown in Table 2.

Risk of bias of included studies, evaluated through Cochrane's methods, showed an overall acceptable quality of selected trials (Figures 2 and 3). 


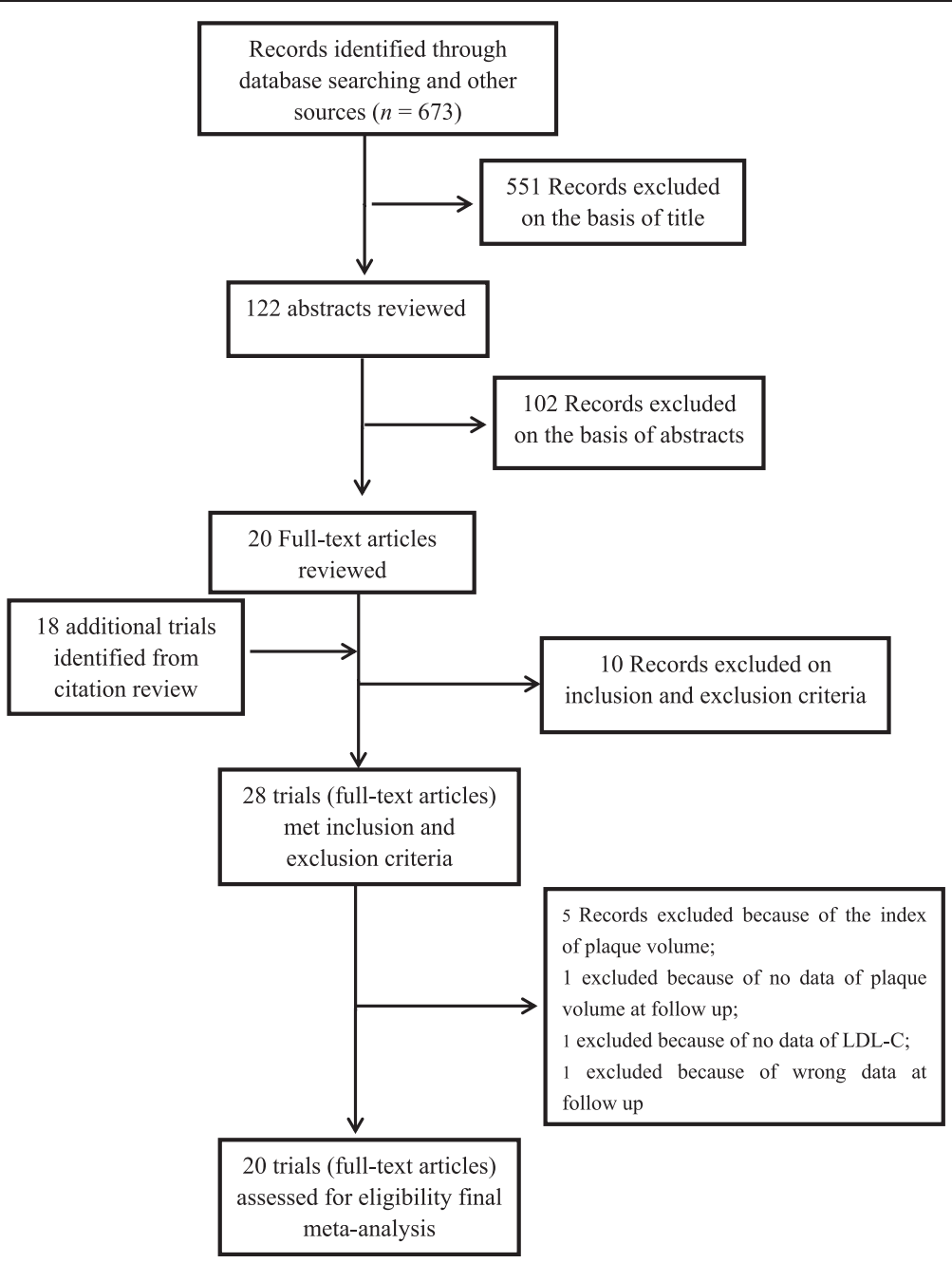

Figure 1 Flow diagram of study-screening process.

The effect of the levels of LDL-C at follow-up on regression of coronary atherosclerotic plaque in Western and Asian For Western, meta-analysis indicated that LDL-C lowering in group $\leq 70 \mathrm{mg} / \mathrm{dL}$ could lead to regression of CAP, but LDL-C lowering in group $>70 \leq 100 \mathrm{HP},>70 \leq 100$ $\mathrm{MP},>70 \leq 100 \mathrm{LP}$ and $>100 \mathrm{mg} / \mathrm{dL}$ could not (Figure 4 , Table 3).

In group $\leq 70 \mathrm{mg} / \mathrm{dL}$ (including three arms) with mean 23.1 months of follow up, the volumes of CAP $\left(160.6 \mathrm{~mm}^{3}\right)$ at follow up were significantly decreased, compared with the volumes $\left(171.4 \mathrm{~mm}^{3}\right)$ at baseline [SMD $-0.156 \mathrm{~mm}^{3}$, 95\% CI (confidence interval) $-0.248 \sim-0.064, p=0.001$ ]. There was no significant heterogeneity among arms $\left(\chi^{2}\right.$ for heterogeneity $=0.33, p=0.886, I^{2}=0 \%$ ).

Sensitivity analyses suggested that LDL-C lowering in group $\leq 70 \mathrm{mg} / \mathrm{dL}$ could lead to regression of CAP with reduction of the CAP volume ranged from $-0.139 \mathrm{~mm}^{3}$ (SMD, 95\% CI: -0.257 -0.021) when the arm of 2006 ASTEROID Ros was omitted to $-0.175 \mathrm{~mm}^{3}$ (SMD,
95\% CI: -0.317 -0.034) when the arm of 2011 SATURN Ros was omitted. No publication bias was found, the values of $p$ by Egger's test was 0.789 .

For Asian, according to the levels of LDL-C at follow-up, the arms were grouped to three groups: $\leq 70,>70 \leq 100 \mathrm{HP}$ and $>100 \mathrm{mg} / \mathrm{dL}$.

LDL-C lowering in group $\leq 70 \mathrm{mg} / \mathrm{dL}$ and $>70 \leq 100 \mathrm{HP}$ could lead to regression of CAP, but LDL-C lowering in group $>100 \mathrm{mg} / \mathrm{dL}$ could not (Figure 5 , Table 3 ).

In group $\leq 70 \mathrm{mg} / \mathrm{dL}$ (including four arms) with mean 6.9 months of follow up and group $>70 \leq 100 \mathrm{HP} \mathrm{mg} / \mathrm{dL}$ (including eight arms) with mean 11.0 months of follow up, the volumes of CAP $\left(179.9,87.5 \mathrm{~mm}^{3}\right.$ respectively) at follow up were significantly decreased, compared with the volumes $\left(192.2,96.4 \mathrm{~mm}^{3}\right.$ respectively) at baseline [SMD $-0.157 \mathrm{~mm}^{3}, 95 \% \mathrm{CI}-0.307 \sim-0.008, p=$ 0.039; SMD $-0.211 \mathrm{~mm}^{3}$, 95\% CI $-0.331 \sim-0.092, p=$ 0.001 ; respectively]. There was no significant heterogeneity among arms $\left(\chi^{2}\right.$ for heterogeneity $=0.24, p=0.955$, 
Table 1 Features of participating trials

\begin{tabular}{|c|c|c|c|c|c|c|c|c|c|c|}
\hline $\begin{array}{l}\text { Authors and } \\
\text { trial name }\end{array}$ & Trial type and location & Objective & Year & $\mathrm{N} \mathrm{T/C}$ & $\begin{array}{l}\text { Study } \\
\text { population }\end{array}$ & $\begin{array}{l}\text { LDL-C at } \\
\text { follow up }\end{array}$ & $\begin{array}{l}\mathrm{LDL}-\mathrm{C} \\
\text { reducing } \\
\text { percentage }\end{array}$ & Treatments & $\begin{array}{l}\text { Follow } \\
\text { up }\end{array}$ & Main Results or Conclusion \\
\hline $\begin{array}{l}\text { Okazaki S }{ }^{11} ; \\
\text { ESTABLISH }\end{array}$ & $\begin{array}{l}\text { RCT: prospective, } \\
\text { open-label, } \\
\text { randomized, } \\
\text { single center } \\
\text { study. Japan }\end{array}$ & $\begin{array}{l}\text { Effects of statins } \\
\text { on changes in } \\
\text { plaque by IVUS }\end{array}$ & 2004 & $24 / 24$ & ACS & $70 / 119$ & $-44 /-0.004$ & Ato 20 vs Diet & 6 & $\begin{array}{l}\text { Plaque volume was sigificantly } \\
\text { reduced in the Ato group } \\
\text { compared with the } \\
\text { control group. }\end{array}$ \\
\hline $\begin{array}{l}\text { Nissen } S^{10}{ }^{10} \\
\text { REVERSAL }\end{array}$ & $\begin{array}{l}\text { RCT: Double-blind, } \\
\text { randomized active } \\
\text { control multicenter } \\
\text { trial; USA }\end{array}$ & $\begin{array}{l}\text { Effects of statins } \\
\text { (intensive or moderate) } \\
\text { on changes in plaque } \\
\text { by IVUS }\end{array}$ & 2004 & $253 / 249$ & $C A D$ & $79 / 110$ & $-46 /-25$ & Ato 80 vs Pra40 & 18 & $\begin{array}{l}\text { Ato reduced progression of } \\
\text { coronary plaque compared } \\
\text { with Pra. Compared with } \\
\text { baseline values, Ato had no } \\
\text { change in atheroma burden, } \\
\text { whereas patients treated with } \\
\text { Pra showed progression of } \\
\text { coronary plaque. }\end{array}$ \\
\hline $\begin{array}{l}\text { Tardif JC' } \\
\text { A-PLUS }\end{array}$ & $\begin{array}{l}\text { RCT: international, } \\
\text { multicenter, } \\
\text { double-blind, } \\
\text { placebo-controlled, } \\
\text { randomized trial. } \\
\text { Canada, USA }\end{array}$ & $\begin{array}{l}\text { Effects of different } \\
\text { dosage of avasimibe } \\
\text { on changes in } \\
\text { plaque by IVUS }\end{array}$ & 2004 & $\begin{array}{l}108 / 98 / \\
117 / 109\end{array}$ & CAD & $\begin{array}{l}100 / 102 / \\
101 / 91\end{array}$ & 7.8/9.1/10.9/1.7 & $\begin{array}{l}\text { Ava50, } 250 \text {, and } \\
750 \text { vs Placebo } \\
\text { on the basis } \\
\text { of } L D L-C<125\end{array}$ & 18 & $\begin{array}{l}\text { Avasimibe did not favorably } \\
\text { alter coronary atherosclerosis } \\
\text { as assessed by IVUS. }\end{array}$ \\
\hline Jensen $\mathrm{LO}^{28}$ & $\begin{array}{l}\text { Open non placebo } \\
\text { controlled serial } \\
\text { investigation; blinded } \\
\text { end-points. Denmark }\end{array}$ & $\begin{array}{l}\text { To investigate the } \\
\text { effect of lipid lowering } \\
\text { by simvastatin on } \\
\text { coronary atherosclerotic } \\
\text { plaque volumes } \\
\text { and lumen. }\end{array}$ & 2004 & 40 & $C A D$ & 85 & -46.3 & $\operatorname{Sim} 40$ & 15 & $\begin{array}{l}\text { Lipid-lowering therapy with } \\
\text { Sim is associated with a } \\
\text { significant plaque regression } \\
\text { in coronary arteries. }\end{array}$ \\
\hline Yokoyama $\mathrm{M}^{12}$ & $\begin{array}{l}\text { RCT: randomized, } \\
\text { single center. Japan }\end{array}$ & $\begin{array}{l}\text { Effects of statins } \\
\text { on changes in } \\
\text { plaque by IVUS }\end{array}$ & 2005 & $29 / 30$ & $\begin{array}{l}\text { stabl } \\
\text { angina }\end{array}$ & $87 / 124$ & $-35 /-0.075$ & Ato 10 vs Diet & 6 & $\begin{array}{l}\text { Treatment with Ato may } \\
\text { reduce volumes of } \\
\text { coronary plaques. }\end{array}$ \\
\hline Kawasaki M ${ }^{13}$ & $\begin{array}{l}\text { RCT: randomization, } \\
\text { open-label, } \\
\text { single-center } \\
\text { study. Japan }\end{array}$ & $\begin{array}{l}\text { Effects of statins on } \\
\text { changes in plaque } \\
\text { by IVUS }\end{array}$ & 2005 & $\begin{array}{l}17 / 18 / \\
17\end{array}$ & $\begin{array}{l}\text { stable } \\
\text { angina }\end{array}$ & $95 / 102 / 149$ & $-39 /-32 /-0.02$ & $\begin{array}{l}\text { Ato 20, Pra } \\
20 \text { vs Diet }\end{array}$ & 6 & $\begin{array}{l}\text { Treatment with Ato and Pra } \\
\text { may not significantly reduce } \\
\text { volumes of coronary plaques. }\end{array}$ \\
\hline Tani $S^{22}$ & $\begin{array}{l}\text { RCT: a prospective, } \\
\text { single-center, } \\
\text { randomized, open } \\
\text { trial. Japan }\end{array}$ & $\begin{array}{l}\text { Investigated the effects } \\
\text { of pravastatin on the } \\
\text { serum levels of MDA-LDL } \\
\text { and coronary } \\
\text { atherosclerosis. }\end{array}$ & 2005 & $52 / 23$ & $\begin{array}{l}\text { stable } \\
\text { angina }\end{array}$ & $104 / 120$ & $-20 /-2.4$ & $\begin{array}{l}\text { Pra } 10-20 \\
\text { vs con }\end{array}$ & 6 & $\begin{array}{l}\text { Plaque volume was sigificantly } \\
\text { reduced in the Pra group } \\
\text { compared with the } \\
\text { control group. }\end{array}$ \\
\hline $\begin{array}{l}\text { Nissen } \text { SE}^{6} \\
\text { ACTIVATE }\end{array}$ & $\begin{array}{l}\text { RCT: randomized, } \\
\text { multicenter. USA }\end{array}$ & $\begin{array}{l}\text { Effects of pactimibe } \\
\text { on changes in plaque } \\
\text { by IVUS }\end{array}$ & 2006 & $206 / 202$ & $C A D$ & $91 / 86$ & $-9.6 /-14.9$ & $\begin{array}{l}\text { Pac100 vs } \\
\text { Placebo }\end{array}$ & 18 & $\begin{array}{l}\text { Pac is not an effective strategy } \\
\text { for limiting atherosclerosis and } \\
\text { may promote atherogenesis. }\end{array}$ \\
\hline $\begin{array}{l}\text { Nissen SE }{ }^{26} \text {; } \\
\text { ASTEROID }\end{array}$ & $\begin{array}{l}\text { Prospective, open-label } \\
\text { blinded end-points. } \\
\text { USA, Germany, } \\
\text { France, Canada }\end{array}$ & $\begin{array}{l}\text { Effects of Statins with } \\
\text { different levels of } \\
\text { LDL-C on changes } \\
\text { in plaque by IVUS }\end{array}$ & 2006 & 349 & $C A D$ & 61 & -53.2 & Ros 40 & 24 & $\begin{array}{l}\text { Therapy using Ros can result } \\
\text { in significant regression } \\
\text { of atherosclerosis. }\end{array}$ \\
\hline
\end{tabular}


Table 1 Features of participating trials (Continued)

\begin{tabular}{|c|c|c|c|c|c|c|c|c|c|c|}
\hline $\begin{array}{l}\text { Yamada T14; } \\
\text { REACH }\end{array}$ & $\begin{array}{l}\text { RCT: open-labeled, } \\
\text { randomized, multicenter } \\
\text { study. Japan }\end{array}$ & $\begin{array}{l}\text { Evaluate the effect of } \\
\text { marked reduction of } L D L-C \\
\text { in patients with } C H D \text { on } \\
\text { progression of atherosclerosis. }\end{array}$ & 2007 & $26 / 32$ & $\begin{array}{l}\text { stable } \\
\text { angina }\end{array}$ & $83 / 115$ & $-43 / 0$ & Ato 5 vs Con & 12 & $\begin{array}{l}\text { Ato treatment prevented the } \\
\text { further progression of } \\
\text { atherosclerosis by maintaining } \\
\text { LDL-C below } 100 \mathrm{mg} / \mathrm{dl} \text { in } \\
\text { patients with CHD. }\end{array}$ \\
\hline $\begin{array}{l}\text { Nissen SEF; } \\
\text { ILLUSTRATE }\end{array}$ & $\begin{array}{l}\text { RCT: prospective, } \\
\text { randomized, multicenter, } \\
\text { double-blind clinical trial. } \\
\text { North America or Europe }\end{array}$ & $\begin{array}{l}\text { Effects of CETP inhibitor on } \\
\text { changes in plaque by IVUS }\end{array}$ & 2007 & $446 / 464$ & $C A D$ & $87 / 70$ & $6.6 /-13.3$ & $\begin{array}{l}\text { Ato } 10-80 \text { vs } \\
\text { Ato }+ \text { Tor } 60 \\
\text { on the basis } \\
\text { of } L D L-C \leq 100 \\
\text { by Ato }\end{array}$ & 24 & $\begin{array}{l}\text { The Tor was associated } \\
\text { with a substantial increase } \\
\text { in } \mathrm{HDL}-\mathrm{C} \text { and decrease in } \\
\mathrm{LDL}-\mathrm{C} \text {, and there was no } \\
\text { significant decrease in the } \\
\text { progression of coronary } \\
\text { atherosclerosis. }\end{array}$ \\
\hline $\begin{array}{l}\text { Nissen } \mathrm{SE}^{25} \text {; } \\
\text { PERISCOPE }\end{array}$ & $\begin{array}{l}\text { RCT: prospective, } \\
\text { randomized, multicenter, } \\
\text { double-blind clinical } \\
\text { trial. USA }\end{array}$ & $\begin{array}{l}\text { To compare the effects of } \\
\text { pioglitazone, and glimepiride } \\
\text { on the progression of } \\
\text { coronary atherosclerosis } \\
\text { in patients with type } 2 \\
\text { diabete and CAD }\end{array}$ & 2008 & $181 / 179$ & $C A D, D M$ & $96.1 / 95.6$ & $1.8 / 2.2$ & $\begin{array}{l}\text { Gli1- } 4 \mathrm{mg} \text { vs Pio } \\
15-45 \mathrm{mg} \text { on } \\
\text { bases of statins } \\
\text { therapy }\end{array}$ & 18 & $\begin{array}{l}\text { In patients with type } 2 \text { diabetes } \\
\text { and CAD, treatment with Pio } \\
\text { resulted in a significantly lower } \\
\text { rate of progression of coronary } \\
\text { atherosclerosis compared } \\
\text { with Gli. }\end{array}$ \\
\hline $\begin{array}{l}\text { Nissen SE } \text { SE}^{24} \\
\text { STRADIVARIUS }\end{array}$ & $\begin{array}{l}\text { RCT: Randomized, } \\
\text { double-blinded, } \\
\text { placebo -controlled, } \\
\text { 2-group, parallel-group } \\
\text { trial. North America, } \\
\text { Europe, and Australia }\end{array}$ & $\begin{array}{l}\text { The effect of rimonabant } \\
\text { on regression of coronary } \\
\text { disease in patients with } \\
\text { the metabolic syndrome } \\
\text { and CAD }\end{array}$ & 2008 & $335 / 341$ & $\begin{array}{l}\text { CAD, } \\
\text { Obesity }\end{array}$ & $87.6 / 86.3$ & $-4.7 /-3.6$ & $\begin{array}{l}\text { Rim } 20 \mathrm{mg} \text { vs } \\
\text { Placebo on bases } \\
\text { of statins therapy }\end{array}$ & 18 & $\begin{array}{l}\text { Rim can reduce progression } \\
\text { of coronary plaque, and } \\
\text { increase HDL-C levels, } \\
\text { decrease triglyceride levels. }\end{array}$ \\
\hline $\begin{array}{l}\text { Hiro } T^{20} \\
\text { JAPAN-ÁCS }\end{array}$ & $\begin{array}{l}\text { RCT: prospective, } \\
\text { randomized, open-label, } \\
\text { parallel group, } \\
\text { multicenter. Japan }\end{array}$ & $\begin{array}{l}\text { Effects of statins on } \\
\text { changes in plaque } \\
\text { by IVUS }\end{array}$ & 2009 & $127 / 125$ & ACS & $84 / 81$ & $-36 /-36$ & Ato 20 vs Pit 4 & 10 & $\begin{array}{l}\text { The administration of Pit or } \\
\text { Ato in patients with ACS } \\
\text { equivalently resulted in } \\
\text { significant regression of } \\
\text { coronary plaque volume. }\end{array}$ \\
\hline $\begin{array}{l}\text { Takayama T; } \\
\operatorname{cosmOS}^{29}\end{array}$ & $\begin{array}{l}\text { Prospective, open-label } \\
\text { blinded end-points } \\
\text { multicenter trial. Japan }\end{array}$ & $\begin{array}{l}\text { Evaluate the effect of } \\
\text { rosuvastatin on plaque } \\
\text { volume in patients } \\
\text { with stable CAD, including } \\
\text { those receiving prior } \\
\text { lipid-lowering therapy }\end{array}$ & 2009 & 126 & $\begin{array}{l}\text { stable } \\
\text { angina }\end{array}$ & 83 & -38.6 & Ros $<20$ & 14 & $\begin{array}{l}\text { Ros exerted significant } \\
\text { regression of coronary } \\
\text { plaque volume in Japanese } \\
\text { patients with stable CAD. }\end{array}$ \\
\hline $\begin{array}{l}\text { Rodés-Cabau; } \\
\text { ERASE }^{23}\end{array}$ & $\begin{array}{l}\text { RCT: multicenter } \\
\text { randomized placebo- } \\
\text { controlled. Canada }\end{array}$ & $\begin{array}{l}\text { Evaluate the early effects } \\
\text { of newly initiated statin } \\
\text { therapy on coronary } \\
\text { atherosclerosis as } \\
\text { evaluated by IVUS. }\end{array}$ & 2009 & $38 / 36$ & ACS & $77 / 63$ & $8.5 /-37$ & $\begin{array}{l}\text { Before ACS vs } \\
\text { After ACS }\end{array}$ & $<2$ & $\begin{array}{l}\text { Newly initiated statin therapy } \\
\text { is associated with rapid } \\
\text { regression of coronary } \\
\text { atherosclerosis. }\end{array}$ \\
\hline Nasu $K^{30}$ & $\begin{array}{l}\text { Prospective and } \\
\text { multicenter study } \\
\text { with nonrandomized } \\
\text { and non-blinded design, } \\
\text { but blinded end. Japan }\end{array}$ & $\begin{array}{l}\text { Evaluate the effect of } \\
\text { treatment with statins } \\
\text { on the progression } \\
\text { of coronary atherosclerotic } \\
\text { plaques of a nonculprit } \\
\text { vessel by serial IVUS. }\end{array}$ & 2009 & $40 / 39$ & $\begin{array}{l}\text { stable } \\
\text { angina }\end{array}$ & $98.1 / 121$ & $-32.3 /-1.1$ & Flu 60 vs Con & 12 & $\begin{array}{l}\text { One-year lipid-lowering } \\
\text { therapy by Flu showed } \\
\text { significant regression } \\
\text { of plaque volume. }\end{array}$ \\
\hline
\end{tabular}


Table 1 Features of participating trials (Continued)

\begin{tabular}{|c|c|c|c|c|c|c|c|c|c|c|}
\hline Hong $\mathrm{MK}^{15}$ & $\begin{array}{l}\text { RCT: randomized } \\
\text { control trial. Korea. }\end{array}$ & $\begin{array}{l}\text { Evaluated the effects } \\
\text { of statin treatments } \\
\text { for each component } \\
\text { of coronary plaques. }\end{array}$ & 2009 & $50 / 50$ & $\begin{array}{l}\text { stable } \\
\text { angina }\end{array}$ & $78 / 64$ & $-34.5 /-44.8$ & Sim 20 vs Ros 10 & 12 & $\begin{array}{l}\text { Statin treatments might } \\
\text { be associated with significant } \\
\text { changes in necrotic core and } \\
\text { fibrofatty plaque volume. }\end{array}$ \\
\hline $\begin{array}{l}\text { Nicholls SJ; } \\
\text { SATURN }{ }^{16}\end{array}$ & $\begin{array}{l}\text { RCT: a prospective, } \\
\text { randomized, multicenter, } \\
\text { double-blind clinical } \\
\text { trial. USA }\end{array}$ & $\begin{array}{l}\text { Compare the effect of } \\
\text { these two intensive statin } \\
\text { regimens on the progression } \\
\text { of coronary atherosclerosis. }\end{array}$ & 2011 & $519 / 520$ & $\mathrm{CHD}$ & $70.2 / 62.6$ & $-41.5 /-47.8$ & Ato 80 vs Ros 40 & 24 & $\begin{array}{l}\text { Maximal doses of Ros and } \\
\text { Ato resulted in significant } \\
\text { regression of coronary } \\
\text { atherosclerosis. }\end{array}$ \\
\hline $\begin{array}{l}\text { Lee } \mathrm{CW}^{17} \text {; } \\
\text { ARTMAP }\end{array}$ & $\begin{array}{l}\text { RCT: a prospective, } \\
\text { single-center, open-label, } \\
\text { randomized comparison } \\
\text { trial. Korea. }\end{array}$ & $\begin{array}{l}\text { Compared the effects of } \\
\text { atorvastatin } 20 \text { mg/day } \\
\text { versus rosuvastatin } \\
10 \text { mg/day on mild } \\
\text { coronary atherosclerotic } \\
\text { plaques. }\end{array}$ & 2012 & $143 / 128$ & $\begin{array}{l}\text { stable } \\
\text { angina }\end{array}$ & $56 / 53$ & $-47 /-49$ & Ato 20 vs Ros 10 & 6 & $\begin{array}{l}\text { Usual doses of Ato and } \\
\text { Ros induced significant } \\
\text { regression of coronary } \\
\text { atherosclerosis in } \\
\text { statin-naive patients. }\end{array}$ \\
\hline
\end{tabular}

Abbreviations: T Treatment, C Control, RCT randomized controlled trials, IVUS Intravascular ultrasound, CAD Coronary artery disease, ACS Acute coronary syndrome, CHD Coronary heart disease, Ato Atorvastatin, Ros Rosuvastatin, Pra Pravastatin, Pit Pitavastatin, Sim Simvastatin, Flu Fluvastatin, Con Control, Pac Pactimibe, Tor Torcetrapib, Ava 50, 250, 750, Avasimibe 50, 250, 750 mg, T/C Treat/Control, Gli Glimepiride, Pio Pioglitazone, Rim Rimonabant. 
Table 2 The levels of LDL-C at baseline and follow up in each arm of included trials

\begin{tabular}{|c|c|c|c|c|c|}
\hline \multirow[t]{2}{*}{ Authors } & \multirow[t]{2}{*}{ Trial name } & \multirow{2}{*}{$\begin{array}{l}\text { Management } \\
\text { in each arm }\end{array}$} & \multirow[t]{2}{*}{$\mathbf{N}$} & \multicolumn{2}{|l|}{ LDL-C level } \\
\hline & & & & At baseline & At follow-up \\
\hline Tardif JC & A-PLUS & Avasimibe50 & 108 & $92.8 \pm 1.7$ & $100^{*}$ \\
\hline Tardif JC & A-PLUS & Avasimibe250 & 98 & $93.4 \pm 1.6$ & $101.9^{*}$ \\
\hline Tardif JC & A-PLUS & Avasimibe750 & 117 & $91.4 \pm 1.6$ & $101.4^{*}$ \\
\hline Tardif JC & A-PLUS & Placebo & 109 & $89.6 \pm 1.6$ & $91.1^{*}$ \\
\hline Okazaki S & ESTABLISH & Control & 24 & $123.9 \pm 35.3$ & $119.4 \pm 24.6$ \\
\hline Okazaki S & ESTABLISH & Atorvastatin & 24 & $124.6 \pm 34.5$ & $70.0 \pm 25.0$ \\
\hline Yokoyama M & & Control & 30 & $131.5 \pm 23 \#$ & $124.5 \pm 24.1 \#$ \\
\hline Yokoyama M & & Atorvastatin & 29 & $133 \pm 13$ & $87 \pm 29$ \\
\hline Nissen SE & REVERSAL & Atorvastatin & 253 & $150.2 \pm 27.9$ & $78.9 \pm 30.2$ \\
\hline Nissen SE & REVERSAL & Pravastatin & 249 & $150.2 \pm 25.9$ & $110.4 \pm 25.8$ \\
\hline Nissen SE & ACTIVATE & Pactimibe & 206 & $101.4 \pm 27.7$ & 91.3 \\
\hline Nissen SE & ACTIVATE & Placebo & 202 & $101.5 \pm 31.1$ & 86.4 \\
\hline Nissen SE & ILLUSTRATE & Atorvastatin & 446 & $84.3 \pm 18.9$ & $87.2 \pm 22.6$ \\
\hline Nissen SE & ILLUSTRATE & Atorva + torcetrapib & 464 & $83.1 \pm 19.7$ & $70.1 \pm 25.4$ \\
\hline Kawasaki M & & Control & 17 & $152 \pm 20$ & $149 \pm 24$ \\
\hline Kawasaki M & & Pravastatin & 18 & $149 \pm 19$ & $102 \pm 13$ \\
\hline Kawasaki M & & Atorvastatin & 17 & $155 \pm 22$ & $95 \pm 15$ \\
\hline Hiro T & JAPAN-ACS & Pitavastatin & 125 & $130.9 \pm 33.3$ & $81.1 \pm 23.4$ \\
\hline Hiro T & JAPAN-ACS & Atorvastatin & 127 & $133.8 \pm 31.4$ & $84.1 \pm 27.4$ \\
\hline Nissen SE & ASTEROID & Rosuvastatin & 349 & $130.4 \pm 34.3$ & $60.8 \pm 20.0$ \\
\hline Takayama T & COSMOS & Rosuvastatin & 126 & $140.2 \pm 31.5$ & $82.9 \pm 18.7$ \\
\hline Lee CW & ARTMAP & Atorvastatin & 143 & $110 \pm 31$ & $56 \pm 18$ \\
\hline Lee CW & ARTMAP & Rosuvastatin & 128 & $109 \pm 31$ & $53 \pm 18$ \\
\hline Yamada T & REACH & Atorvastatin & 26 & $123 \pm 17$ & $83 \pm 22$ \\
\hline Yamada T & REACH & Control & 32 & $115 \pm 14$ & $115 \pm 30$ \\
\hline Nasu K & & Fluvastatin & 40 & $144.9 \pm 31.5$ & $98.1 \pm 12.7$ \\
\hline Nasu K & & Control & 39 & $122.3 \pm 18.9$ & $121.0 \pm 21.2$ \\
\hline Nicholls SJ & SATURN & Atorvastatin & 519 & $119.9 \pm 28.9$ & $70.2 \pm 1.0$ \\
\hline Nicholls SJ & SATURN & Rosuvastatin & 520 & $120.0 \pm 27.3$ & $62.6 \pm 1.0$ \\
\hline Hong MK & & Simvastatin & 50 & $119 \pm 30$ & $78 \pm 20$ \\
\hline Hong MK & & Rosuvastatin & 50 & $116 \pm 28$ & $64 \pm 21$ \\
\hline Tani S & & Pravastatin & 52 & $130 \pm 38$ & $104 \pm 20$ \\
\hline Tani S & & Control & 23 & $123 \pm 28$ & $120 \pm 30$ \\
\hline Rodés-C Bef & ERASE & Statins before ACS & 38 & $71 \pm 23$ & $77 \pm 25$ \\
\hline Rodés-C Aft & ERASE & Statins after ACS & 36 & $100 \pm 30$ & $63 \pm 17$ \\
\hline Jensen LO & & Simvastatin & 40 & $158.7 \pm 30.6$ & $85.1 \pm 22.1$ \\
\hline Nissen SE & PERISCOPE & Statins + Gli & 181 & $94.4 \pm 32.9$ & $96.1 \pm 30.4$ \\
\hline Nissen SE & PERISCOPE & Statins + Pio & 179 & $93.5 \pm 30.7$ & $95.6 \pm 28.9$ \\
\hline Nissen SE & STRADIVARIUS & Statins + Rim & 335 & $91.9 \pm 27.9$ & $87.6 \pm 30.5$ \\
\hline Nissen SE & STRADIVARIUS & Statins + Con & 341 & $89.5 \pm 32.2$ & $86.3 \pm 30.3$ \\
\hline
\end{tabular}

Note: *calculated on the bases of baseline levels and change percentage at follow up ${ }^{5}$. ${ }^{\#}$ calculated according to Figure 2 in the paper ${ }^{12}$. 


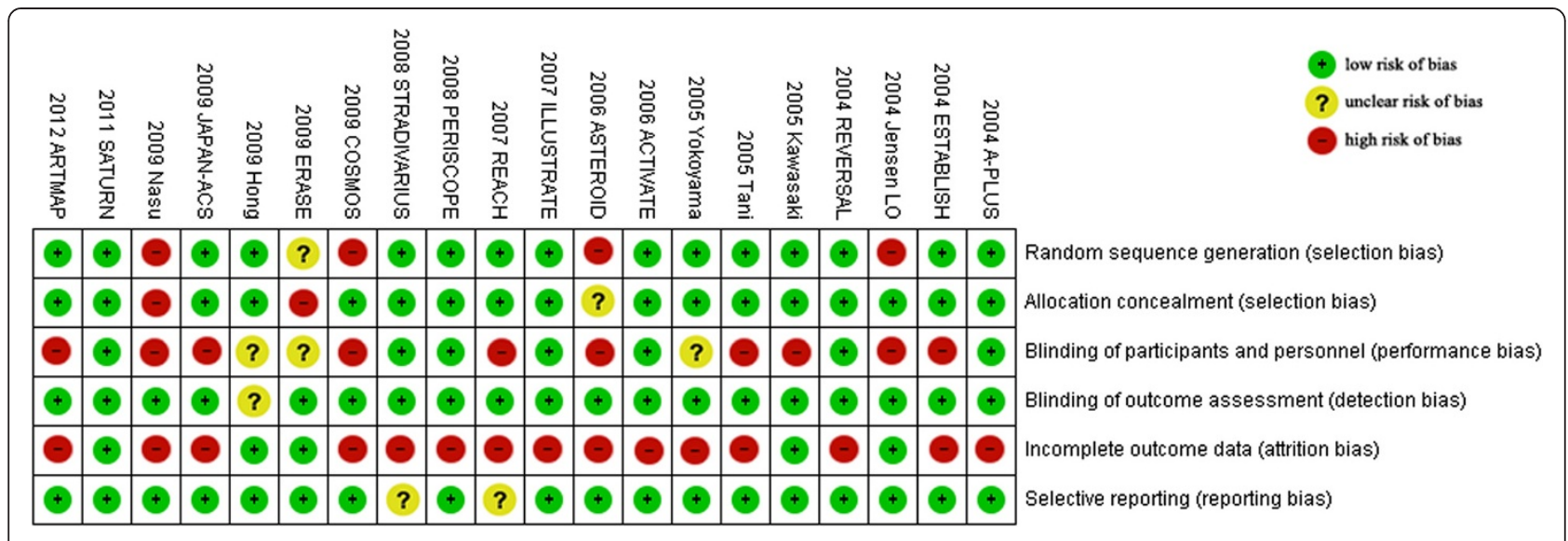

Figure 2 Methodological quality summary of each included trial.

$I^{2}=0 \%$ for group $\leq 70 \mathrm{mg} / \mathrm{dL} ; \chi^{2}$ for heterogeneity = 2.68, $p=0.913, I^{2}=0 \%$ for group $>70 \leq 100 \mathrm{HP} \mathrm{mg} / \mathrm{dL}$ ).

Sensitivity analyses suggested that LDL-C lowering in group $>70 \leq 100 \mathrm{HP} \mathrm{mg} / \mathrm{dL}$ could lead to regression of CAP with reduction of the CAP volume ranged from $-0.177 \mathrm{~mm}^{3}$ (SMD, 95\% CI: -0.314 -0.040) when the arm of 2009 JAPAN-ACS Ato was omitted to $-0.231 \mathrm{~mm}^{3}$ (SMD, 95\% CI: $-0.368 \sim-0.094$ ) when the arm of 2009 COSMOS Ros was omitted; but that LDL-C lowering in group $\leq 70 \mathrm{mg} / \mathrm{dL}$ could not significantly lead to regression of CAP with reduction of the CAP volume when the arm of 2012 ARTMAP Ros or 2012 ARTMAP Ato was omitted (Table 3).

No publication bias was found, the values of $p$ by Egger's test for group $\leq 70$ and $>70 \leq 100 \mathrm{HP} \mathrm{mg} / \mathrm{dL}$ were $0.970,0.083$ respectively.

The effect of the LDL-C reducing percentage at follow-up on regression of CAP in Western and Asian

For Western, meta-analysis showed that LDL-C lowering in group $\geq 40<50, \geq 50 \%$ could lead to regression of CAP, but LDL-C lowering in group $<0, \geq 0<30 \%$ and $\geq 30<40$ could not (Figure 6, Table 3).
In group $\geq 40<50 \%$ (including four arms) with mean 22.6 months of follow up, the volumes of CAP $\left(143.1 \mathrm{~mm}^{3}\right)$ at follow up were significantly decreased, compared with the volumes $\left(148.8 \mathrm{~mm}^{3}\right)$ at baseline (SMD $-0.095 \mathrm{~mm}^{3}, 95 \% \mathrm{CI}-0.171 \sim-0.019, p=0.014$ ). There was no significant heterogeneity among arms $\left(\chi^{2}\right.$ for heterogeneity $=1.64, P=0.651, I^{2}=0 \%$ ).

Sensitivity analyses showed that LDL-C lowering in group $\geq 40<50$ could still lead to regression of CAP with reduction of the plaque volume ranged from $-0.065 \mathrm{~mm}^{3}(95 \% \mathrm{CI}-0.163 \sim 0.032)$ when the arm of 2011 SATURN Ros was omitted to $-0.116 \mathrm{~mm}^{3}$ (SMD, 95\% CI -0.201 -0.032) when 2004 REVERSAL Ato was omitted. Publication bias analysis suggested the values of $p$ by Egger's test were 0.804 .

In group group $<0, \geq 0<30 \%$ and $\geq 30<40$, metaanalysis were showed in Table 3.

For Asian, according to the reducing percentage of LDL-C at follow-up, the arms were grouped to following groups: $\geq 0<30, \geq 30<40, \geq 40<50$.

LDL-C lowering in group $\geq 30<40, \geq 40<50 \%$ could lead to regression of CAP, but LDL-C lowering in group $\geq 0<$ $30 \%$ could not (Figure 7, Table 3).

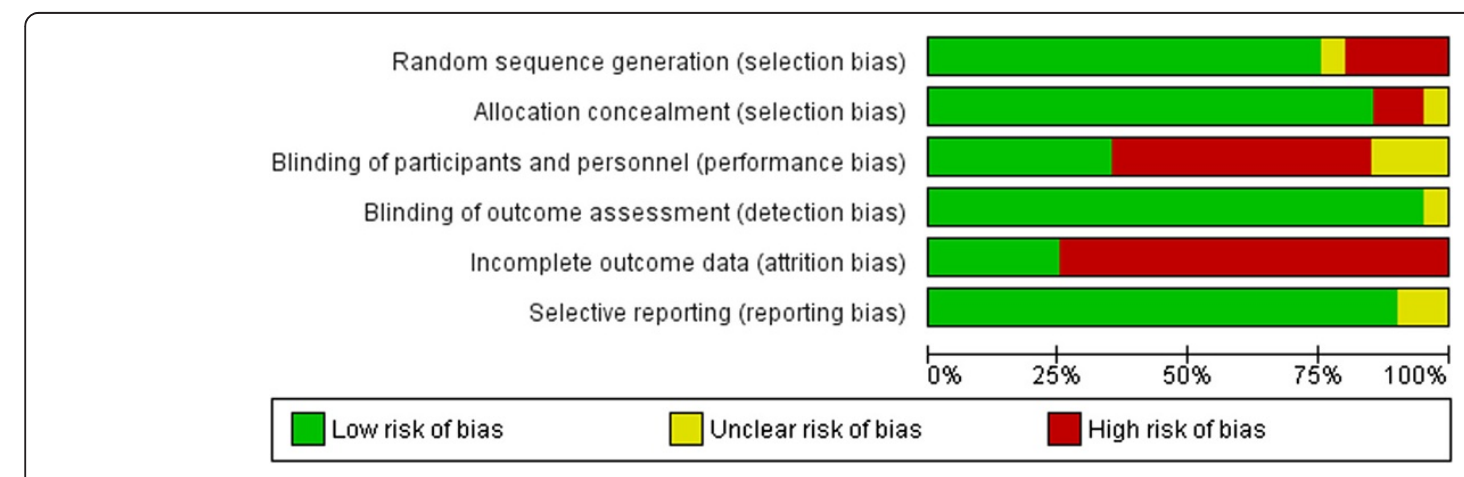

Figure 3 Methodological quality graph: each methodological quality item presented as percentages across all included studies. 
In group $\geq 30<40 \%$ (including nine arms) with mean 10.9 months of follow up, and group $\geq 40<50 \%$ (including four arms) with mean 6.9 months of follow up, the volumes of CAP (90.0, $179.9 \mathrm{~mm}^{3}$ respectively) at follow up were significantly decreased, compared with the volumes (98.6, $192.2 \mathrm{~mm}^{3}$ respectively) at baseline (SMD $-0.206 \mathrm{~mm}^{3}$, 95\% CI $-0.324 \sim-0.088, p=0.001$; SMD $-0.157 \mathrm{~mm}^{3}$, $95 \%$ CI $-0.307 \sim-0.008, p=0.039$; respectively). There was no significant heterogeneity among arms $\left(\chi^{2}\right.$ for heterogeneity $=2.91, P=0.840, I^{2}=0 \% ; X^{2}$ for heterogeneity $=0.33, p=0.955, I^{2}=0 \%$; for group $\geq 30<40$, and group $\geq 40<50$ respectively).

Sensitivity analyses showed that LDL-C lowering in group $\geq 30<40 \%$ could still lead to regression of CAP with reduction of the plaque volume ranged from $-0.172 \mathrm{~mm}^{3}$ (95\% CI -0.306 -0.038) when the arm of 2009 JAPAN-ACS Ato was omitted to $-0.223 \mathrm{~mm}^{3}$ (SMD, 95\% CI -0.357 -0.089) when 2009 COSMOS Ros was omitted. Publication bias analysis suggested that bias was significant with 0.004 of $p$ value by Egger's test.
Mean levels of LDL-C at baseline and follow up, mean reducing percentage of LDL-C in each group were showed in Table 4.

The effect of lowering LDL-C by statins on regression of coronary atherosclerotic plaque in Western and Asian

For Western, atorvastatin, rosuvastatin, pravastatin and simvastatin were used in trials to investigate the effects of LDL-C lowering on CAP. Meta-analysis indicated that LDL-C lowering by rosuvastatin could lead to regression of CAP, but LDL-C lowering by atorvastatin, pravastatin, and simvastatin could not (Figure 8 , Table 5).

LDL-C lowering by rosuvastatin (mean $40.0 \mathrm{mg}$ daily for mean 24 months) could significantly decrease the volumes of CAP at follow up, compared with the volumes at baseline (SMD $-0.158 \mathrm{~mm}^{3}, 95 \% \mathrm{CI}:-0.253 \sim-0.064, p=$ $0.001)$. There was no significant heterogeneity among $\operatorname{arms}\left(\chi^{2}\right.$ for heterogeneity $\left.=0.18, p=0.672, I^{2}=0 \%\right)$. 
Table 3 Results of meta-analysis in each group and mean CAP volume in each group at baseline and follow up in Western and Asian

\begin{tabular}{|c|c|c|c|c|c|c|c|c|c|c|}
\hline \multirow[t]{2}{*}{ Group } & & \multirow[t]{2}{*}{$\begin{array}{l}\text { Included arms } \\
\text { (case) }\end{array}$} & \multirow{2}{*}{$\begin{array}{l}\text { CAP volume } \\
\text { at baseline } \\
\left(\mathrm{mm}^{3}\right)\end{array}$} & \multirow{2}{*}{$\begin{array}{l}\text { CAP volume } \\
\text { at follow up } \\
\left(\mathrm{mm}^{3}\right)\end{array}$} & \multirow[t]{2}{*}{ Pooled SMD $(95 \% \mathrm{Cl}, p)$} & \multicolumn{2}{|c|}{$\begin{array}{l}\text { Heterogeneity } \\
\text { test }\end{array}$} & \multicolumn{2}{|l|}{ Sensitivity analyses } & \multirow[t]{2}{*}{$\begin{array}{l}\text { Egger's } \\
\text { test }\end{array}$} \\
\hline & & & & & & $\mathrm{X}^{2}$ test $(p)$ & $1^{2}$ & Lower SMD (95\% Cl) & Upper SMD (95\% Cl) & \\
\hline \multirow{10}{*}{ Western } & $<70 \mathrm{mg}$ & $3(905)$ & $171.4 \pm 32.7$ & $160.6 \pm 29.7$ & $-0.156(-0.248 \sim-0.064,0.001)$ & $0.33(0.886)$ & 0 & $\begin{array}{l}-0.139(-0.257 \sim-0.021) \\
\text { Without } 2006 \text { ASTEROID Ros }\end{array}$ & $\begin{array}{l}-0.175(-0.317 \sim-0.034) \\
\text { Without } 2011 \text { SATURN Ros }\end{array}$ & 0.789 \\
\hline & $>70 \leq 100 \mathrm{HPmg}$ & $3(812)$ & $151.9 \pm 30.4$ & $147.9 \pm 31.9$ & $-0.065(-0.136 \sim 0.032,0.189)$ & $0.71(0.699)$ & 0 & & & 0.987 \\
\hline & $>70 \leq 100 \mathrm{MPmg}$ & $5(1548)$ & $195.8 \pm 2.3$ & $191.8 \pm 4.7$ & $-0.045(-0.115 \sim-0.026,0.215)$ & $1.59(0.811)$ & 0 & & & 0.500 \\
\hline & $>70 \leq 100$ LPmg & $6(1061)$ & $201.2 \pm 15.1$ & $197.3 \pm 15.0$ & $-0.045(-0.130 \sim 0.040,0.301)$ & $1.14(0.950)$ & 0 & & & 0.241 \\
\hline & $>100 \mathrm{mg}$ & $3(464)$ & $197.6 \pm 3.5$ & $201.1 \pm 1.9$ & $0.034(-0.094 \sim 0.163,0.601)$ & $0.03(0.984)$ & 0 & & & \\
\hline & $>50 \%$ & $1(349)$ & $212.2 \pm 81.3$ & $197.5 \pm 79.1$ & $-0.183(-0.332 \sim-0.035,0.016)$ & & & & & \\
\hline & $>40 \leq 50 \%$ & $4(1332)$ & $148.8 \pm 24.0$ & $143.1 \pm 25.6$ & $-0.095(-0.171 \sim-0.019,0.014)$ & $1.64(0.651)$ & 0 & $\begin{array}{l}-0.065(-0.163 \sim 0.032) \\
\text { Without } 2011 \text { SATURN Ros }\end{array}$ & $\begin{array}{l}-0.116(-0.201 \sim-0.032) \\
\text { Without } 2004 \text { REVERSAL Ato }\end{array}$ & 0.804 \\
\hline & $>30 \leq 40 \%$ & 1(36) & $169.1 \pm 77.3$ & $161.5 \pm 75.2$ & $-0.099(-0.561 \sim 0.363,0.675)$ & $0.00(0.000)$ & 0 & & & \\
\hline & $>0 \leq 30 \%$ & 6(1797) & $195.6 \pm 2.1$ & $192.9 \pm 5.1$ & $-0.032(-0.098 \sim 0.033,0.335)$ & $2.45(0.784)$ & 0 & & & \\
\hline & $<0 \%$ & $8(1276)$ & $201.2 \pm 13.8$ & $198.3 \pm 13.8$ & $-0.034(-0.111 \sim 0.044,0.396)$ & $1.55(0.981)$ & 0 & & & 0.087 \\
\hline \multirow{6}{*}{ Asian } & $<70 \mathrm{mg}$ & $4(345)$ & $192.2 \pm 59.9$ & $179.9 \pm 53.0$ & $-0.157(-0.307 \sim-0.008,0.039)$ & $0.24(0.955)$ & 0 & $\begin{array}{l}-0.126(-0.314 \sim 0.063) \\
\text { Without } 2012 \text { ARTMAP Ros }\end{array}$ & $\begin{array}{l}-0.187(-0.383 \sim 0.008) \\
\text { Without } 2012 \text { ARTMAP Ato }\end{array}$ & 0.970 \\
\hline & $>70 \leq 100 \mathrm{HPmg}$ & $8(540)$ & $96.4 \pm 99.3$ & $87.5 \pm 92.0$ & $-0.211(-0.331 \sim-0.092,0.001)$ & $2.68(0.913)$ & 0 & $\begin{array}{l}-0.177(-0.314 \sim-0.040) \\
\text { Without } 2009 \text { JAPAN-ACS Ato }\end{array}$ & $\begin{array}{l}-0.231(-0.368 \sim-0.094) \\
\text { Without } 2009 \text { cosmOS Ros }\end{array}$ & 0.083 \\
\hline & $>100$ mg & $8(235)$ & $133.0 \pm 139.6$ & $134.3 \pm 143.8$ & $-0.029(-0.210 \sim 0.152,0.750)$ & $2.14(0.952)$ & 0 & & & \\
\hline & $>40 \leq 50 \%$ & $4(345)$ & $192.2 \pm 56.9$ & $179.9 \pm 53.0$ & $-0.157(-0.307 \sim-0.008,0.039)$ & $0.33(0.955)$ & 0 & $\begin{array}{l}-0.126(-0.314 \sim 0.063) \\
\text { Without } 2012 \text { ARTMAP Ros }\end{array}$ & $\begin{array}{l}-0.187(-0.383 \sim 0.008) \\
\text { Without } 2012 \text { ARTMAP Ato }\end{array}$ & 0.970 \\
\hline & $>30 \leq 40 \%$ & $9(558)$ & $98.6 \pm 98.5$ & $90.0 \pm 91.6$ & $-0.206(-0.324 \sim-0.088,0.001)$ & $2.91(0.840)$ & 0 & $\begin{array}{l}-0.172(-0.306 \sim-0.038) \\
\text { Without } 2009 \text { JAPAN-ACS Ato }\end{array}$ & $\begin{array}{l}-0.223(-0.357 \sim-0.089) \\
\text { Without } 2009 \text { cosmOS Ros }\end{array}$ & 0.004 \\
\hline & $>0 \leq 30 \%$ & $7(217)$ & $130.2 \pm 144.9$ & $131.8 \pm 149.4$ & $-0.028(-0.216 \sim 0.161,0.773)$ & $2.14(0.907)$ & 0 & & & \\
\hline
\end{tabular}




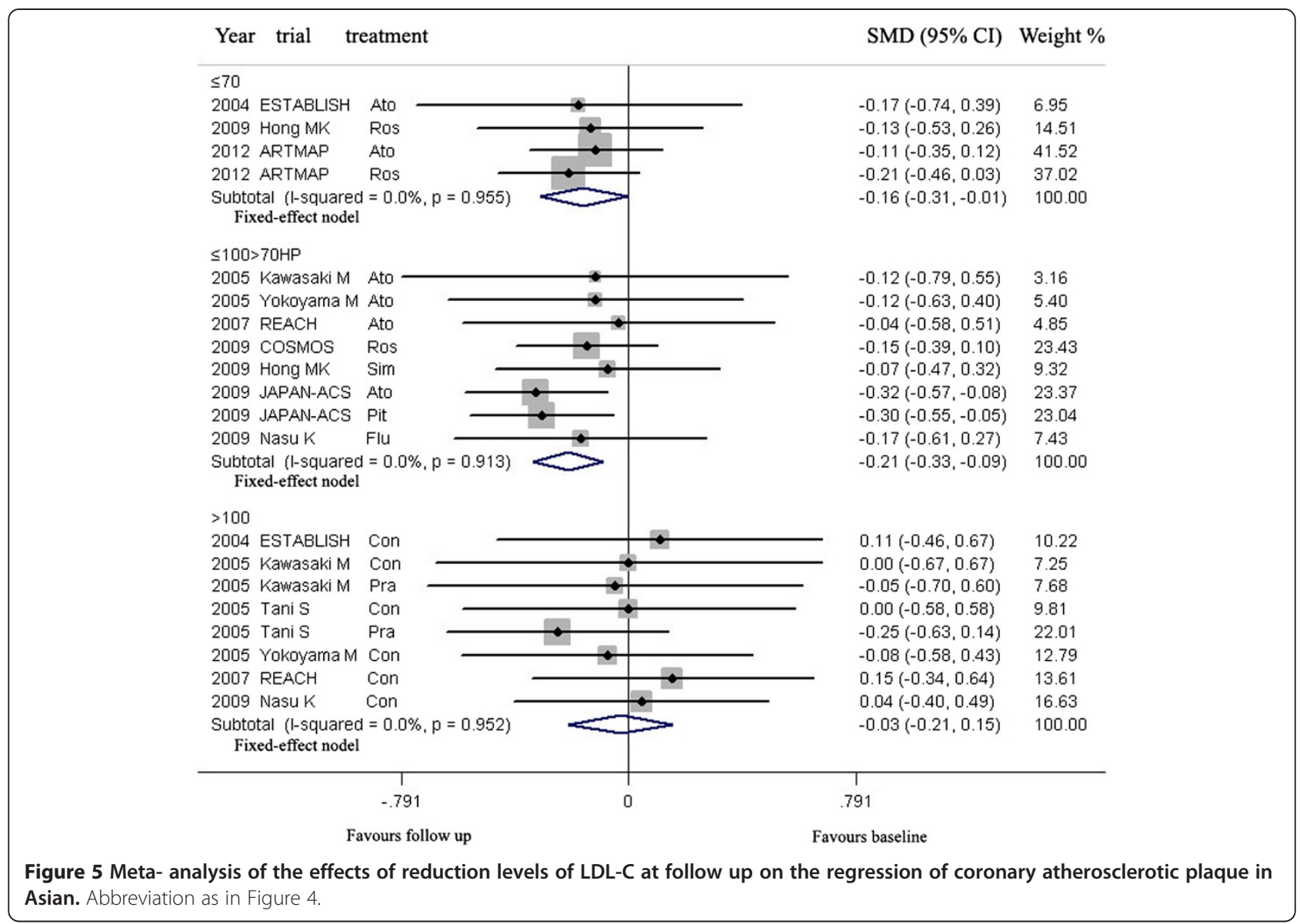

Sensitivity analyses suggested that lowering LDL-C by rosuvastatin could lead to regression of CAP with reduction of the plaque volume ranged from $-0.142 \mathrm{~mm}^{3}$ (SMD, 95\% CI: $-0.263 \sim-0.020$ ) when the arm of 2006 ASTEROID Ros was omitted to $-0.183 \mathrm{~mm}^{3}$ (SMD, 95\% CI: $-0.332 \sim-0.035)$ when the arm of 2011 SATURN Ros was omitted. But publication bias was found, the values of $p$ by Egger's test was 0.000 (Table 5).

For Asian, atorvastatin, rosuvastatin, pitavastatin, pravastatin, fluvastatin and simvastatin were used in trials to investigate the effects of LDL-C lowering on CAP. Meta-analysis indicated that LDL-C lowering by rosuvastatin, atorvastatin could lead to regression of CAP, but LDL-C lowering by pitavastatin, pravastatin, fluvastatin and simvastatin could not (Figure 9, Table 5).

LDL-C lowering by rosuvastatin (mean $14.1 \mathrm{mg}$ daily for mean 10.3 months), atorvastatin (mean $18.9 \mathrm{mg}$ daily for mean 7.8 months) could significantly decrease the volumes of CAP at follow up, compared with the volumes at baseline (SMD $-0.172 \mathrm{~mm}^{3}$, 95\% CI: $-0.331 \sim-0.012, p=$ 0.035; SMD -0.185 , 95\% CI: $-0.330 \sim-0.040, p=0.013$; respectively). There was no significant heterogeneity among arms $\left(\chi^{2}\right.$ for heterogeneity $=0.17, p=0.917, I^{2}=0 \%$ for rosuvastatin; $\chi^{2}$ for heterogeneity $=1.94, p=0.858$, $I^{2}=0 \%$ for atorvastatin).

Sensitivity analyses suggested that lowering LDL-C by rosuvastatin could not significantly lead to regression of CAP when the arm of 2012 ARTMAP Ros or 2009 COSMOS Ros was omitted. Also, Lowering LDL-C by atorvastatin could not significantly lead to regression of CAP when the arm of 2009 JAPAN-ACS Ato was omitted. No publication bias was found, the values of $p$ by Egger's test for rosuvastatin and atorvastatin group were $0.660,0.456$ respectively (Table 5 ).

Intensity of lowering LDL-C by different statins was shown in Table 6. Rosuvastatin and atorvastatin could reduce LDL-C by more than $40 \%$.

\section{The difference between Western and Asian in usage of statins}

The meta analysis showed that rosuvastatin and atorvastatin can regress CAP (Table 5). LDL-C levels, intensity of lowering LDL-C by rosuvastatin and atorvastatin, its dosage and duration were compared between Western and Asian (Table 7). Intensity of lowering LDL-C by rosuvastatin and atorvastatin in Western group were 


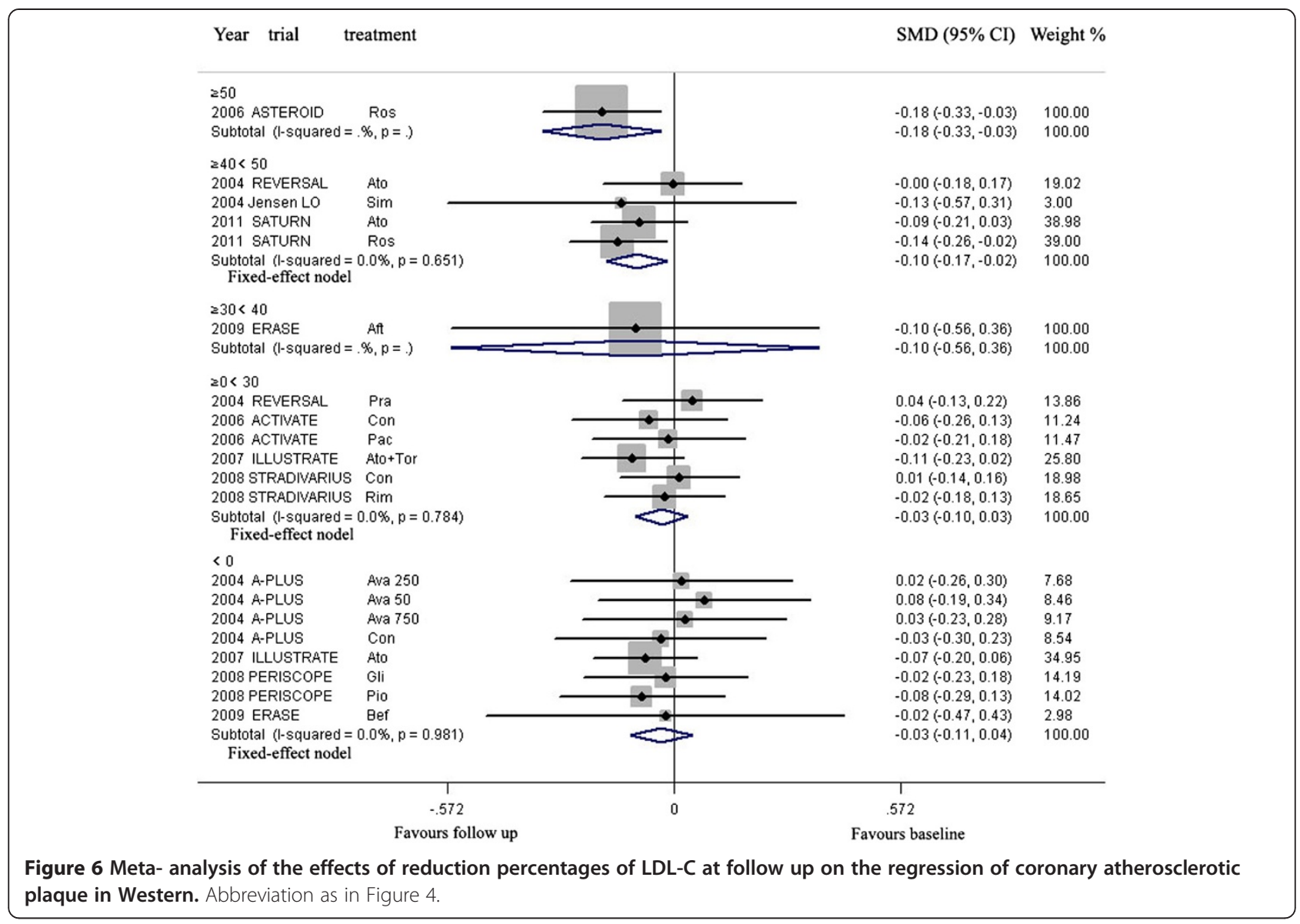

similar to that in Asian group, but the dosages of rosuvastatin and atorvastatin in Asian group were significantly lower than those in Western group, and the duration of statins administration in Asian group were significantly shorter than those in Western, as showed in Table 7.

\section{Discussion}

This meta-analysis revealed that intensive LDL-C lowering can regress CAP both in Western and Asian. For regressing $\mathrm{CAP}$, the dosage of statins administrated in Westerns was different from that in Asians. Asians need lower dosage of atorvastatin or rosuvastatin than Westerns though there was no difference between Westerns and Asians in pharmacokinetic and pharmacodynamic study [32,33].

\section{The effect difference of LDL-C lowering on CAP between Western and Asian}

For Western including American, Canadian, German, French, English, Australian and Dane [10,5-7,16,23-26,28], the meta-analysis (Table 3) in subgroup $\leq 70 \mathrm{mg}$ and $\geq 40<50 \%$ of Western indicated that LDL-C level lowering to $<69.3 \mathrm{mg}$ or reducing by $>45 \%$ for 22.6 months of follow up (Table 4) could lead to regression of CAP, but the meta-analysis (Table 3) in subgroup $>70 \leq 100 \mathrm{HP} \mathrm{mg}$ of Western showed that LDL-C level lowering to $73.2 \mathrm{mg}$ or reducing by $43.6 \%$ for 21.7 months of follow up (Table 4) was not enough for regressing CAP.

For Asian including Japanese and Korean [20,11-15, $17,22,29,30]$, the meta-analysis in subgroup $\leq 70 \mathrm{mg}$ and $\geq 40<50 \%$ of Asian indicated that LDL-C level lowering to $57.0 \mathrm{mg}$ or reducing by $47.2 \%$ for 6.9 months of follow up could lead to regression of CAP, but sensitivity analyses showed that LDL-C lowering in this two subgroup could not significantly lead to regression of CAP when the arm of 2012 ARTMAP Ros or 2012 ARTMAP Ato was omitted (Table 3). The meta-analysis in subgroup $\geq 30<40 \%$ of Asian indicated that LDL-C level lowering to $84.6 \mathrm{mg}$ or reducing by $36.0 \%$ for 10.9 months of follow up could also lead to regression of CAP, but publication bias was significant. The meta-analysis in subgroup $>70 \leq 100 \mathrm{HP} \mathrm{mg}$ of Asian with good sensitivity and no publication bias indicated that LDL-C level lowering to $84.0 \mathrm{mg}$ or reducing 


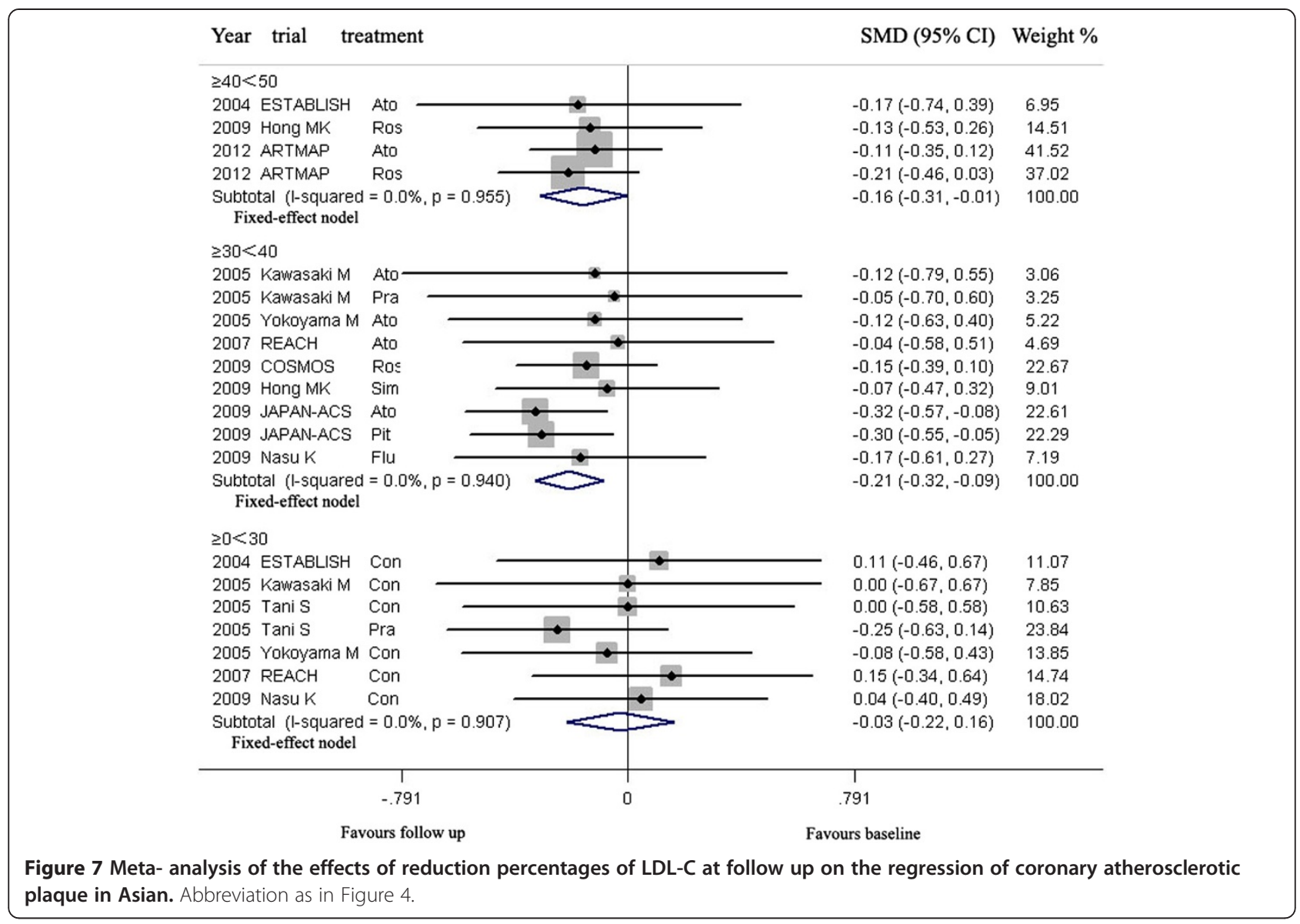

by $36.1 \%$ for 11 months of follow up with could lead to regression of CAP (Table 3).

Taken all the results of meta-analysis together, for Western, it was recommended that LDL-C level might be reduced by $>45 \%$ or to a target level $<69 \mathrm{mg} / \mathrm{dL}$ for regressing CAP; for Asian, LDL-C level might be reduced by $>36 \%$ or to a target level $<84 \mathrm{mg} / \mathrm{dL}$.

\section{Different effects of statins on Westerns and Asians}

Whether statins has different effect on Westerns and Asians remains to be settled.

The study by Lee E et al. [34] and MEGA Study [35] suggested statins have different effects on Westerns and Asians. In 2005, Lee E et al. [34] prospectively examined the pharmacokinetics of rosuvastatin in White and Asian individuals living in Singapore, and reported that plasma exposure to rosuvastatin and its metabolites was significantly higher in Chinese, Malay, and Asian-Indian subjects compared with Western subjects living in the same environment. But the mechanisms underlying ethnic differences in rosuvastatin disposition remain to be unearthed [36]. MEGA Study [35] indicated that a small dose of pravastatin that was half the dose administered to western patients, reduced LDL-C by $19-22 \%$ (which is lower than that reductions of $23-35 \%$ in western patients), but could substantially reduce the risk of coronary heart disease in Japanese.

But two meta-analysis did not demonstrate the difference of rosuvastatin and atorvastatin on Westerns and Asians. The meta-analysis including the 36 trials of pharmacodynamics of rosuvastatin in Western and Asian hypercholesterolemia patients did not confirm that there was significant difference in the exposureresponse relationship for LDL-C reduction between Westerners and Asians [33].The meta-analysis including 22 pharmacokinetic studies also demonstrated no differences in the systemic exposure to atorvastatin between Asian and Caucasian subjects [32].

Our meta-analysis revealed that there were difference of rosuvastatin and atorvastatin in lowering LDL$\mathrm{C}$ and regressing CAP between Westerns and Asians. The meta-analysis of rosuvastatin including 2 trials with 869 Western patients indicated that $40 \mathrm{mg}$ of rosuvastatin daily for 24 months with reducing LDL-C by $49.9 \%$ could regress CAP. But the meta-analysis of 
Table 4 Levels and reducing percentage of LDL-C and duration in each group in Western and Asian (Mean \pm SD)

\begin{tabular}{|c|c|c|c|c|c|c|c|}
\hline Group & & $N$ & $\begin{array}{l}\text { Mean LDL-C at } \\
\text { baseline (mg) }\end{array}$ & $\begin{array}{l}\text { Mean LDL-C at } \\
\text { follow up (mg) }\end{array}$ & $\begin{array}{l}\text { Mean reducing } \\
\text { percentage }\end{array}$ & $\begin{array}{l}\text { Actual range of } \\
\text { reducing percentage }\end{array}$ & Duration (month) \\
\hline \multirow{10}{*}{ Western } & $\leq 70 \mathrm{mg}$ & 905 & $123.2 \pm 6.9$ & $61.9 \pm 0.9$ & $49.4 \pm 3.5$ & $37 \sim 53$ & $23.1 \pm 4.3$ \\
\hline & $>70 \leq 100 \mathrm{HPmg}$ & 812 & $131.3 \pm 15.2$ & $73.6 \pm 4.8$ & $43.2 \pm 2.2$ & $41.5 \sim 46.7$ & $21.7 \pm 3.1$ \\
\hline & $>70 \leq 100 \mathrm{MPmg}$ & 1548 & $91.3 \pm 6.9$ & $82.4 \pm 8.2$ & $9.0 \pm 4.5$ & $3.6 \sim 14.9$ & $19.8 \pm 2.7$ \\
\hline & $>70 \leq 100$ LPmg & 1061 & $88.5 \pm 5.5$ & $91.5 \pm 5.4$ & $-4.7 \pm 2.5$ & $-1.7 \sim-8.5$ & $19.9 \pm 4.5$ \\
\hline & $>100 \mathrm{mg}$ & 464 & $123.4 \pm 28.9$ & $106.3 \pm 4.4$ & $8.7 \pm 17.5$ & $-10.9 \sim 25.0$ & $18.0 \pm 0.0$ \\
\hline & $>50 \%$ & 349 & $130.4 \pm 0.0$ & $60.8 \pm 0.0$ & $53.4 \pm 0.0$ & $53.4 \sim 53.4$ & $24.0 \pm 0.0$ \\
\hline & $>40 \leq 50 \%$ & 1332 & $126.9 \pm 13.1$ & $69.3 \pm 6.5$ & $45.0 \pm 2.8$ & $41.5 \sim 47.8$ & $22.6 \pm 2.7$ \\
\hline & $>30 \leq 40 \%$ & 36 & $100.2 \pm 30.2$ & $63.1 \pm 17.4$ & 37.0 & $37 \sim 37$ & $2.0 \pm 0.0$ \\
\hline & $>0 \leq 30 \%$ & 1797 & $99.4 \pm 21.4$ & $86.2 \pm 12.2$ & $11.2 \pm 6.9$ & $3.6 \sim 25.0$ & $19.5 \pm 2.6$ \\
\hline & $<0 \%$ & 1276 & $89.1 \pm 5.3$ & $93.2 \pm 6.2$ & $-5.6 \pm 3.1$ & $-1.7 \sim-10.9$ & $19.6 \pm 4.2$ \\
\hline \multirow{6}{*}{ Asian } & $\leq 70 \mathrm{mg}$ & 345 & $111.5 \pm 4.3$ & $57.0 \pm 5.0$ & $47.2 \pm 1.7$ & $44 \sim 49$ & $6.9 \pm 2.1$ \\
\hline & $>70 \leq 100 \mathrm{HPmg}$ & 540 & $134.2 \pm 7.8$ & $84.0 \pm 5.0$ & $36.1 \pm 1.8$ & $32.3 \sim 39.0$ & $11.0 \pm 2.2$ \\
\hline & $>100 \mathrm{mg}$ & 235 & $128.6 \pm 10.5$ & $117.2 \pm 11.9$ & $7.3 \pm 10.7$ & $0 \sim 32$ & $7.8 \pm 2.8$ \\
\hline & $>40 \leq 50 \%$ & 345 & $111.5 \pm 4.3$ & $57.0 \pm 5.0$ & $47.2 \pm 1.7$ & $44 \sim 49$ & $6.9 \pm 2.1$ \\
\hline & $>30 \leq 40 \%$ & 558 & $134.7 \pm 8.1$ & $84.6 \pm 5.8$ & $36.0 \pm 1.9$ & $32 \sim 39$ & $10.9 \pm 2.4$ \\
\hline & $>0 \leq 30 \%$ & 217 & $126.9 \pm 9.1$ & $118.3 \pm 11.5$ & $5.3 \pm 8.3$ & $0 \sim 20.0$ & $8.0 \pm 2.8$ \\
\hline
\end{tabular}

rosuvastatin including 3 trials with 304 Asian patients showed that $14.1 \mathrm{mg}$ of rosuvastatin daily for 10.3 months with reducing LDL-C by $44.0 \%$ could also regress CAP though the result of sensitivity analyses is not as good as that in Western (Table 5). The meta- analysis of atorvastatin including 2 trials with 772 Western patients showed that $80 \mathrm{mg}$ of atorvastatin daily for 22 months with reducing LDL-C by $43.0 \%$ could not significantly regress CAP. But the metaanalysis of atorvastatin including 6 trials with 366

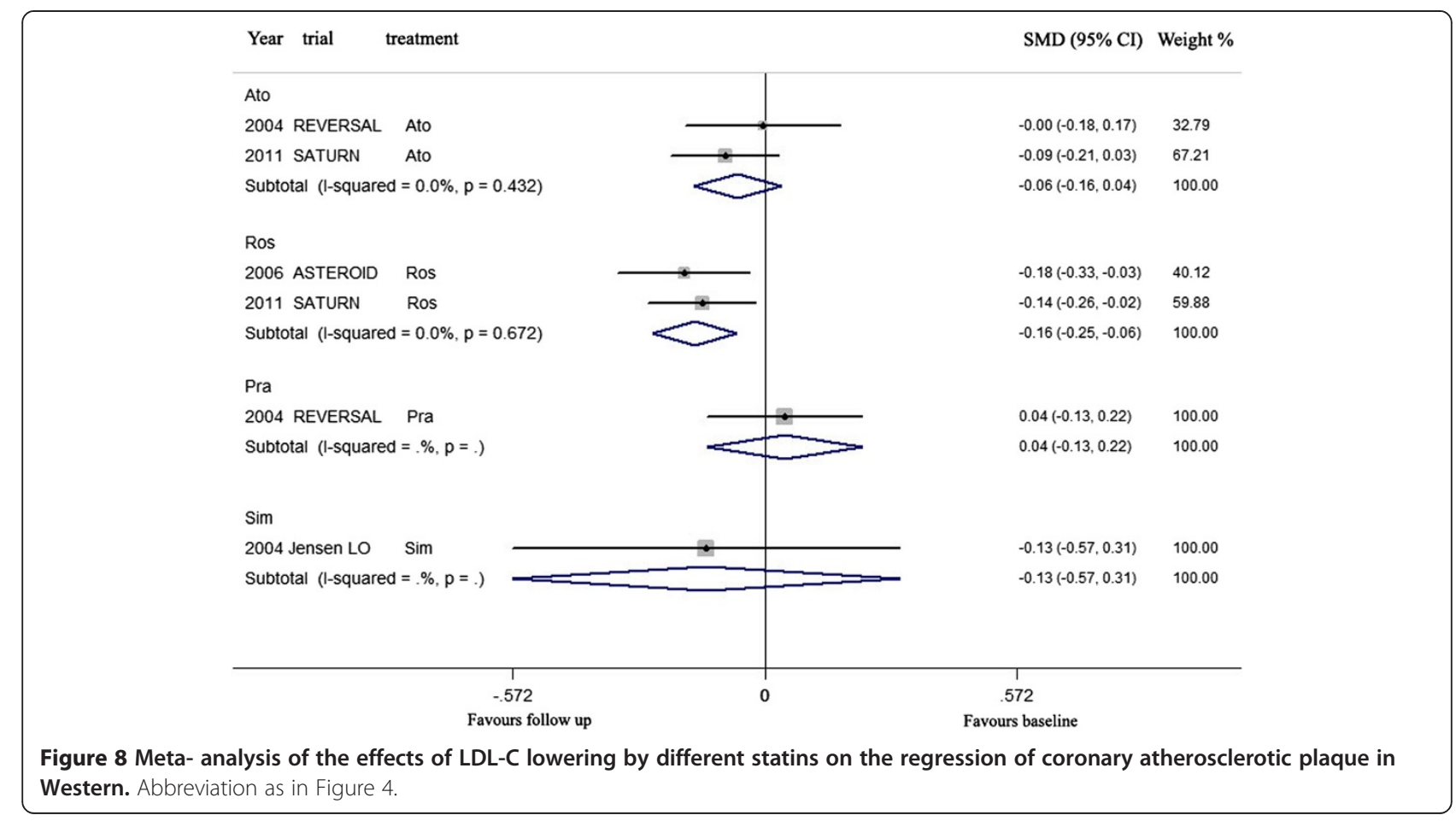


Table 5 Results of meta-analysis in different statins groups in Western and Asian

\begin{tabular}{|c|c|c|c|c|c|c|c|c|}
\hline \multirow[t]{2}{*}{ Group } & & \multirow{2}{*}{$\begin{array}{l}\text { Included arms } \\
\text { (and case) }\end{array}$} & \multirow[t]{2}{*}{ Pooled SMD $(95 \% \mathrm{Cl}, p)$} & \multicolumn{2}{|c|}{ Heterogeneity test } & \multicolumn{2}{|l|}{ Sensitivity analyses } & \multirow{2}{*}{$\begin{array}{l}\text { Egger's } \\
\text { test }\end{array}$} \\
\hline & & & & $\mathrm{X}^{2}$ test $(p)$ & $1^{2}$ & Lower SMD (95\% Cl) & Upper SMD (95\% Cl) & \\
\hline & Rosuvastatin & $2(869)$ & $-0.158(-0.253 \sim-0.064,0.001)$ & $0.18(0.672)$ & 0 & $\begin{array}{l}-0.142(-0.263 \sim-0.020) \\
\text { Without } 2006 \text { ASTEROID Ros }\end{array}$ & $\begin{array}{l}-0.183(-0.332 \sim-0.035) \\
\text { Without } 2011 \text { SATURN Ros }\end{array}$ & 0.000 \\
\hline \multirow[t]{5}{*}{ Western } & Atorvastatin & $2(772)$ & $-0.062(-0.162 \sim 0.038,0.225)$ & $0.62(0.432)$ & 0 & & & 0.000 \\
\hline & Pravastatin & $1(249)$ & $0.045(-0.131 \sim 0.221,0.616)$ & & & & & \\
\hline & Simvastatin & $1(40)$ & $-0.133(-0.572 \sim 0.306,0.552)$ & & & & & \\
\hline & Rosuvastatin & $3(304)$ & $-0.172(-0.331 \sim-0.012,0.035)$ & $0.17(0.917)$ & 0 & $\begin{array}{l}-0.143(-0.352 \sim 0.066) \\
\text { Without } 2012 \text { ARTMAP Ros }\end{array}$ & $\begin{array}{l}-0.189(-0.397 \sim 0.019) \\
\text { Without } 2009 \text { COSMOS Ros }\end{array}$ & 0.660 \\
\hline & Atorvastatin & $6(366)$ & $-0.185(-0.330 \sim-0.040,0.013)$ & $1.94(0.858)$ & 0 & $\begin{array}{l}-0.113(-0.292 \sim 0.068) \\
\text { Without } 2009 \text { JAPAN-ACS Ato }\end{array}$ & $\begin{array}{l}-0.230(-0.417 \sim-0.044) \\
\text { Without } 2012 \text { ARTMAP Ato }\end{array}$ & 0.456 \\
\hline \multirow[t]{4}{*}{ Asian } & Pravastatin & $2(70)$ & $-0.197(-0.529 \sim 0.135,0.245)$ & $0.26(0.608)$ & 0 & & & \\
\hline & Pitavastatin & $1(125)$ & $-0.304(-0.553 \sim-0.055,0.017)$ & & & & & \\
\hline & Fluvastatin & $1(40)$ & $-0.169(-0.608 \sim 0.270,0.450)$ & & & & & \\
\hline & Simvastatin & $1(50)$ & $-0.074(-0.467 \sim 0.318,0.710)$ & & & & & \\
\hline
\end{tabular}




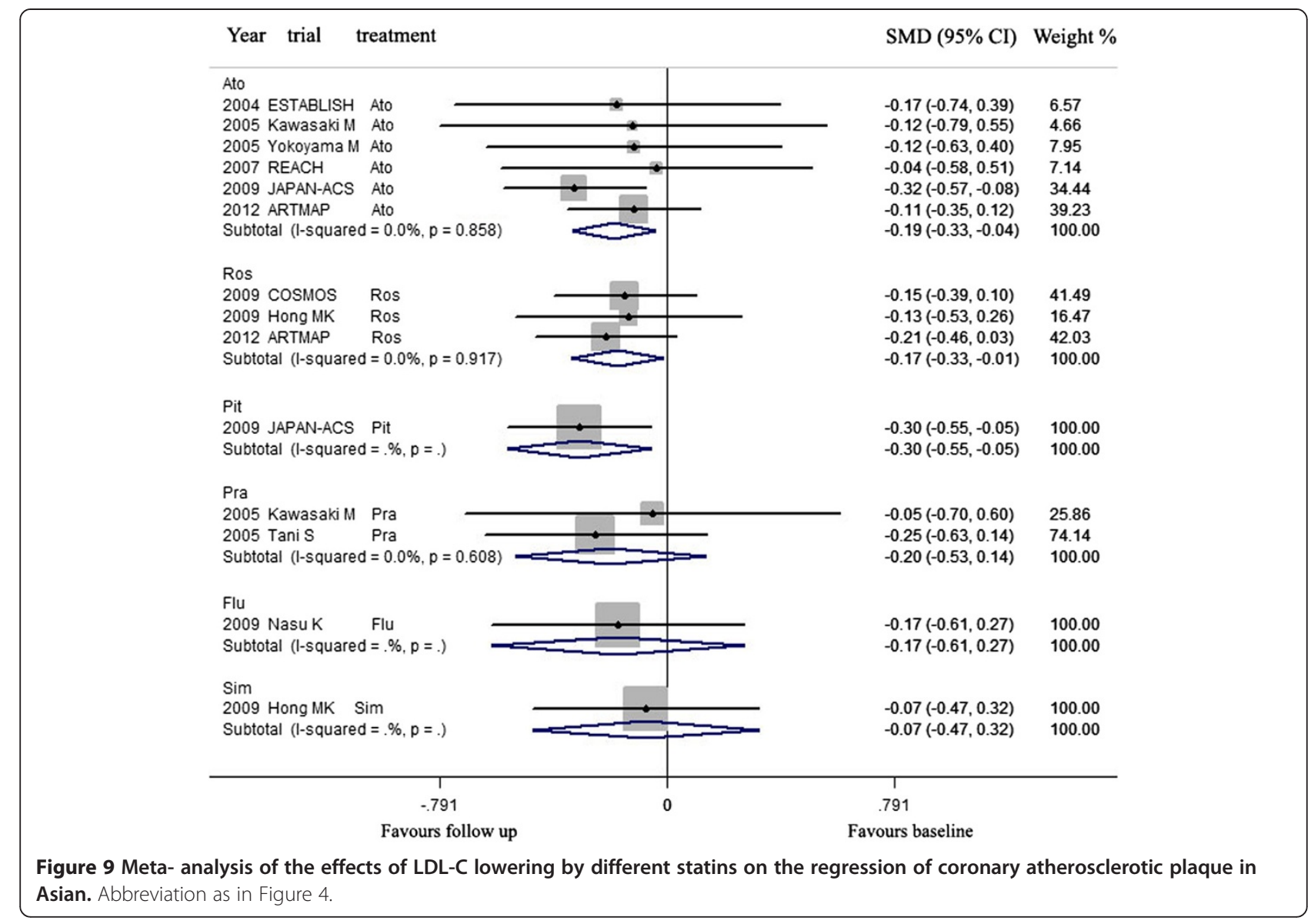

Asian patients demonstrated that $18.9 \mathrm{mg}$ of atorvastatin daily for 7.8 months with reducing LDL-C by $40.7 \%$ could significantly regress CAP though the result of sensitivity analyses is not as good as that expected (Table 5).
Comparison between Western and Asian in using rosuvastatin and atorvastatin indicated that the dosages of rosuvastatin and atorvastatin in Asian group were significantly lower than those in Western (Table 7).

Table 6 Levels and reducing percentage of LDL-C, dosage and duration in different statin group in Western and Asian (Mean \pm SD)

\begin{tabular}{lllllllll}
\hline Group & & N & Age & $\begin{array}{l}\text { MeanLDL-C at } \\
\text { baseline }(\mathbf{m g})\end{array}$ & $\begin{array}{l}\text { MeanLDL-C at } \\
\text { follow up }(\mathbf{m g})\end{array}$ & $\begin{array}{l}\text { Mean reducing } \\
\text { percentage }\end{array}$ & Statin dosage (mg) & Duration (month) \\
\hline \multirow{6}{*}{ Western } & Rosuvastatin & 869 & $57.8 \pm 0.6$ & $124.2 \pm 5.1$ & $61.9 \pm 0.9$ & $49.9 \pm 2.6$ & $40.0 \pm 0.0$ & $24.0 \pm 0.0$ \\
& Atorvastatin & 772 & $57.2 \pm 1.0$ & $129.8 \pm 14.2$ & $73.1 \pm 4.1$ & $43.0 \pm 2.1$ & $80.0 \pm 0.0$ & $22.0 \pm 2.8$ \\
& Pravastatin & 249 & $56.6 \pm 0.0$ & $150.2 \pm 0.0$ & $110.4 \pm 0.0$ & $25.0 \pm 0.0$ & $40.0 \pm 0.0$ & $18.0 \pm 0.0$ \\
& Simvastatin & 40 & $57.7 \pm 0.0$ & $158.7 \pm 0.0$ & $85.1 \pm 0.0$ & $46.7 \pm 0.0$ & $40.0 \pm 0.0$ & $25.0 \pm 0.0$ \\
\hline \multirow{6}{*}{ Asian } & Rosuvastatin & 304 & $58.9 \pm 3.3$ & $123.1 \pm 14.6$ & $67.2 \pm 13.8$ & $44.0 \pm 4.8$ & $14.1 \pm 4.9$ & $10.3 \pm 3.7$ \\
& Atorvastatin & 366 & $60.9 \pm 3.0$ & $124.1 \pm 12.7$ & $72.9 \pm 14.2$ & $40.7 \pm 5.5$ & $18.9 \pm 2.9$ & $7.8 \pm 2.2$ \\
& Pitavastatin & 125 & $62.5 \pm 11.5$ & $130.9 \pm 33.3$ & $81.1 \pm 23.4$ & $36.2 \pm 19.5$ & 4 & $8 \sim 12$ \\
& Pravastatin & 70 & $64.0 \pm 1.8$ & $134.9 \pm 8.4$ & $130.5 \pm 0.9$ & $23.1 \pm 5.3$ & $16.3 \pm 2.2$ & $6.0 \pm 0.0$ \\
& Fluvastatin & 40 & $63.0 \pm 10.0$ & $144.9 \pm 31.5$ & $98.1 \pm 12.7$ & 32.3 & 60 & 12 \\
& Simvastatin & 50 & $58.0 \pm 0.0$ & $119.0 \pm 0.0$ & $78.0 \pm 0.0$ & $34.5 \pm 0.0$ & $20.0 \pm 0.0$ & $12.0 \pm 0.0$ \\
\hline
\end{tabular}


Table 7 Comparison between Western and Asian in rosuvastatin and atorvastatin

\begin{tabular}{|c|c|c|c|c|c|c|}
\hline & \multicolumn{3}{|c|}{ Rosuvastatin } & \multicolumn{3}{|l|}{ Atorvastatin } \\
\hline & Western & Asian & $\mathbf{p}$ & Western & Asian & $\mathrm{p}$ \\
\hline N/arm & $869 / 2$ & $304 / 3$ & & $772 / 2$ & $366 / 6$ & \\
\hline Mean LDL-C at baseline (mg) & $124.2 \pm 5.1$ & $123.1 \pm 14.6$ & 0.928 & $129.8 \pm 14.2$ & $124.1 \pm 12.7$ & 0.610 \\
\hline Mean LDL-C at follow up (mg) & $61.9 \pm 0.9$ & $67.2 \pm 13.8$ & 0.642 & $73.1 \pm 4.1$ & $72.9 \pm 14.2$ & 0.986 \\
\hline LDL-C Mean reducing percentage & $49.9 \pm 2.6$ & $44.0 \pm 4.8$ & 0.221 & $43.0 \pm 2.1$ & $40.7 \pm 5.5$ & 0.600 \\
\hline Statin dosage (mg) & $40.0 \pm 0.0$ & $14.1 \pm 4.9$ & 0.006 & $80.0 \pm 0.0$ & $18.9 \pm 2.9$ & $<0.001$ \\
\hline Duration (month) & $24.0 \pm 0.0$ & $10.3 \pm 3.7$ & 0.016 & $22.0 \pm 2.8$ & $7.8 \pm 2.2$ & $<0.001$ \\
\hline
\end{tabular}

Based on this meta-analysis, reducing LDL-C by $>40 \%$ in Westerns need atorvastatin $80 \mathrm{mg}$ or rosuvastatin $40 \mathrm{mg}$, but in Asians need only atorvastatin $18.9 \mathrm{mg}$ or rosuvastatin $14.1 \mathrm{mg}$. For regressing CAP, $40 \mathrm{mg}$ of rosuvastatin might be daily administrated in Western for 24 months; $14.1 \mathrm{mg}$ of rosuvastatin or $18.9 \mathrm{mg}$ of atorvastatin might be daily administrated in Asian for 10.7 or 7.8 months respectively.

\section{Study limitation}

As with the meta-analysis [3], this study has some limitations. There might be publication bias, difference of the method detected and follow up duration. But those differences in measurements and plaque selection did not affect the change of the target plaque with LDL-C levels. So, it has little effect on homogeneous of studies, and on the relationship between CAP change and LDL-C level. But the trials of single statin on LDL-C and CAP of specific population (for example, 2 trials about atorvastatin on Western with 727 participants or 6 on Asian with 366 in Table 5) were limited, the effect of statin on specific population remains to be investigated. The duration of follow up between Western and Asian was different (Table 4, 6 and 7), and treatment duration might have some effect on CAP regression. But the trials from Asian and Western were respectively meta-analysed in this study. Therefore, the difference in follow-up duration between Asian and Western did not influence the results of the metaanalysis. The CAP regression in short period of statins therapy in Asian suggested that the CAPs in Asian were easily regressed by statins.

This meta-analysis did not investigate the effect of reduction of LDL-C on adverse cardiovascular events because all participants of the included trial must be alive at follow up. But in the Extended-ESTABLISH study, the incidence of adverse cardiovascular events in statin group with CAP regression were reduced to half that seen in the control group [37]. In the Extended JAPAN-ACS study [38], there was no significantly different association of incidence of adverse cardiovascular events with the CAP regression extent, but that greater external elastic membrane volume regression $(<-6.56 \%)$ had a significantly lower incidence of cumulative events than the lesser suggested the importance of CAP regression in reducing adverse cardiovascular events. A meta-analysis [39] included 7864 CAD patients showed that rates of plaque volume regression were significantly associated with the incidence of MI or revascularization.

\section{Conclusions}

LDL-C lowering therapy has a different effect on atherosclerotic plaque between Westerns and Asians. This systemic review demonstrated that there is a different effect of LDL-C lowering on CAP between Westerns and Asians. For regressing CAP, Asians need lower dosage of statins or lower intensity LDL-C lowering therapy (by >36\%) than Westerns (by 45\%).

\section{Abbreviations}

ACAT: Acyl-coenzyme A: cholesterol acyltransferase; ACS: Acute coronary syndrome; ATP III: Adult Treatment Panel III; CAD: Coronary artery disease; CAG: Coronary angiography; CAP: Coronary atherosclerotic plaque; CETP: Cholesteryl ester transfer protein; CHD: Coronary heart disease; IVUS: Intravascular ultrasound; Cl: Confidence interval; LDL-C: Low-density lipoprotein cholesterol; RCT: Randomized controlled trial; SMD: Standardized mean differences.

\section{Competing interests}

The authors declare that they have no competing interests. This study was not funded.

\section{Authors' contributions}

LYF, FQZ, GWQ and ZXJ carried out data extraction, participated in the analysis and drafted the manuscript. CYD and HY participated in the design of the study, helped to draft the manuscript, and participated in its statistical analysis. All authors read and approved the final manuscript.

\section{Author details}

${ }^{1}$ The Department of Cardiology, Chinese PLA General Hospital, Fuxing Road 28, Beijing 100853, China. ${ }^{2}$ The First Department of Geriatric Cardiology, Chinese PLA General Hospital, Beijing 100853, China. ${ }^{3}$ The First Clinics, Administrative and Supportive Bureau, Chinese PLA General Logistics Department, Jia 14, Fuxing Road 22, Beijing 100842, China.

Received: 16 September 2014 Accepted: 12 January 2015 Published: 14 February 2015 


\section{References}

1. Falk E, Shah PK, Fuster V. Coronary plaque disruption. Circulation. 1995;92:657-71.

2. Nissen SE, Yock P. Intravascular ultrasound: novel pathophysiological insights and current clinical applications. Circulation. 2001;103:604-16.

3. Gao WQ, Feng QZ, Li YF, Li YX, Huang Y, Chen YM, et al. Systematic study of the effects of lowering low-density lipoprotein-cholesterol on regression of coronary atherosclerotic plaques using intravascular ultrasound. BMC Cardiovasc Disord. 2014;14:60.

4. Schartl M, Bocksch W, Koschyk DH, Voelker W, Karsch KR, Kreuzer J, et al. Use of intravascular ultrasound to compare effects of different strategies of lipid-lowering therapy on plaque volume and composition in patients with coronary artery disease. Circulation. 2001;104:387-92.

5. Tardif JC, Gregoire J, L'Allier PL, Anderson TJ, Bertrand O, Reeves F, et al. Effects of the acyl coenzyme A:cholesterol acyltransferase inhibitor avasimibe on human atherosclerotic lesions. Circulation. 2004;110:3372-7.

6. Nissen SE, Tuzcu EM, Brewer HB, Sipahi I, Nicholls SJ, Ganz P, et al. Effect of ACAT inhibition on the progression of coronary atherosclerosis. N Engl J Med. 2006;354:1253-63.

7. Nissen SE, Tardif JC, Nicholls SJ, Revkin JH, Shear CL, Duggan WT, et al. Effect of torcetrapib on the progression of coronary atherosclerosis. N Engl J Med. 2007;356:1304-16.

8. Nozue T, Yamamoto S, Tohyama S, Umezawa S, Kunishima T, Sato A, et al. Statin treatment for coronary artery plaque composition based on intravascular ultrasound radiofrequency data analysis. Am Heart J. 2012;163:191-9.e1.

9. Zhang X, Wang H, Liu S, Gong P, Lin J, Lu J, et al. Intensive-dose atorvastatin regimen halts progression of atherosclerotic plaques in new-onset unstable angina with borderline vulnerable plaque lesions. J Cardiovasc Pharmacol Ther. 2013;18:119-25.

10. Nissen SE, Tuzcu EM, Schoenhagen P, Brown BG, Ganz P, Vogel RA, et al. Effect of intensive compared with moderate lipid-lowering therapy on progression of coronary atherosclerosis: a randomized controlled trial. JAMA. 2004;291:1071-80.

11. Okazaki S, Yokoyama T, Miyauchi K, Shimada K, Kurata T, Sato H, et al. Early statin treatment in patients with acute coronary syndrome: demonstration of the beneficial effect on atherosclerotic lesions by serial volumetric intravascular ultrasound analysis during half a year after coronary event: the ESTABLISH Study. Circulation. 2004;110:1061-8.

12. Yokoyama M, Komiyama N, Courtney BK, Nakayama T, Namikawa S, Kuriyama N, et al. Plasma low-density lipoprotein reduction and structural effects on coronary atherosclerotic plaques by atorvastatin as clinically assessed with intravascular ultrasound radio-frequency signal analysis: a randomized prospective study. Am Heart J. 2005;150:287.

13. Kawasaki M, Sano K, Okubo M, Yokoyama H, Ito Y, Murata I, et al. Volumetric quantitative analysis of tissue characteristics of coronary plaques after statin therapy using three-dimensional integrated backscatter intravascular ultrasound. J Am Coll Cardiol. 2005;45:1946-53.

14. Yamada T, Azuma A, Sasaki S, Sawada T, Matsubara H. Randomized evaluation of atorvastatin in patients with coronary heart disease: a serial intravascular ultrasound study. Circ J. 2007;71:1845-50.

15. Hong MK, Park DW, Lee CW, Lee SW, Kim YH, Kang DH, et al. Effects of statin treatments on coronary plaques assessed by volumetric virtual histology intravascular ultrasound analysis. JACC Cardiovasc Interv. 2009:2:679-88

16. Nicholls SJ, Ballantyne CM, Barter PJ, Chapman MJ, Erbel RM, Libby P, et al. Effect of two intensive statin regimens on progression of coronary disease. N Engl J Med. 2011;365:2078-87.

17. Lee CW, Kang SJ, Ahn JM, Song HG, Lee JY, Kim WJ, et al. Comparison of effects of atorvastatin (20 mg) versus rosuvastatin (10 mg) therapy on mild coronary atherosclerotic plaques (from the ARTMAP trial). Am J Cardiol. 2012;109:1700-4

18. Hong YJ, Jeong MH, Hachinohe D, Ahmed K, Choi YH, Cho SH, et al. Comparison of effects of rosuvastatin and atorvastatin on plaque regression in Korean patients with untreated intermediate coronary stenosis. Circ J. 2011;75:398-406.

19. Kovarnik T, Mintz GS, Skalicka H, Kral A, Horak J, Skulec R, et al. Virtual histology evaluation of atherosclerosis regression during atorvastatin and ezetimibe administration: HEAVEN study. Circ J. 2012;76:176-83.

20. Hiro T, Kimura T, Morimoto T, Miyauchi K, Nakagawa Y, Yamagishi M, et al. Effect of intensive statin therapy on regression of coronary atherosclerosis in patients with acute coronary syndrome: a multicenter randomized trial evaluated by volumetric intravascular ultrasound using pitavastatin versus atorvastatin (JAPAN-ACS [Japan assessment of pitavastatin and atorvastatin in acute coronary syndrome] study). J Am Coll Cardiol. 2009;54:293-302.

21. Petronio AS, Amoroso G, Limbruno U, Papini B, De Carlo M, Micheli A, et al. Simvastatin does not inhibit intimal hyperplasia and restenosis but promotes plaque regression in normocholesterolemic patients undergoing coronary stenting: a randomized study with intravascular ultrasound. Am Heart J. 2005;149:520-6.

22. Tani S, Watanabe I, Anazawa T, Kawamata H, Tachibana E, Furukawa K, et al. Effect of pravastatin on malondialdehyde-modified low-density lipoprotein levels and coronary plaque regression as determined by three-dimensional intravascular ultrasound. Am J Cardiol. 2005;96:1089-94.

23. Rodes-Cabau J, Tardif JC, Cossette M, Bertrand OF, Ibrahim R, Larose E, et al. Acute effects of statin therapy on coronary atherosclerosis following an acute coronary syndrome. Am J Cardiol. 2009;104:750-7.

24. Nissen SE, Nicholls SJ, Wolski K, Rodes-Cabau J, Cannon CP, Deanfield JE, et al. Effect of rimonabant on progression of atherosclerosis in patients with abdominal obesity and coronary artery disease: the STRADIVARIUS randomized controlled trial. JAMA. 2008;299:1547-60.

25. Nissen SE, Nicholls SJ, Wolski K, Nesto R, Kupfer S, Perez A, et al. Comparison of pioglitazone vs glimepiride on progression of coronary atherosclerosis in patients with type 2 diabetes: the PERISCOPE randomized controlled trial. JAMA. 2008;299:1561-73.

26. Nissen SE, Nicholls SJ, Sipahi I, Libby P, Raichlen JS, Ballantyne CM, et al. Effect of very high-intensity statin therapy on regression of coronary atherosclerosis: the ASTEROID trial. JAMA. 2006;295:1556-65.

27. Matsuzaki M, Hiramori K, Imaizumi T, Kitabatake A, Hishida H, Nomura M, et al. Intravascular ultrasound evaluation of coronary plaque regression by low density lipoprotein-apheresis in familial hypercholesterolemia: the Low Density Lipoprotein-Apheresis Coronary Morphology and Reserve Trial (LACMART). J Am Coll Cardiol. 2002;40:220-7.

28. Jensen LO, Thayssen P, Pedersen KE, Stender S, Haghfelt T. Regression of coronary atherosclerosis by simvastatin: a serial intravascular ultrasound study. Circulation. 2004;110:265-70.

29. Takayama T, Hiro T, Yamagishi M, Daida H, Hirayama A, Saito S, et al. Effect of rosuvastatin on coronary atheroma in stable coronary artery disease: multicenter coronary atherosclerosis study measuring effects of rosuvastatin using intravascular ultrasound in Japanese subjects (COSMOS). Circ J. 2009;73:2110-7.

30. Nasu K, Tsuchikane E, Katoh O, Tanaka N, Kimura M, Ehara M, et al. Effect of fluvastatin on progression of coronary atherosclerotic plaque evaluated by virtual histology intravascular ultrasound. JACC Cardiovasc Interv. 2009;2:689-96.

31. Hattori K, Ozaki Y, Ismail TF, Okumura M, Naruse H, Kan S, et al. Impact of statin therapy on plaque characteristics as assessed by serial OCT, grayscale and integrated backscatter-IVUS. JACC Cardiovasc Imaging. 2012;5:169-77.

32. Gandelman K, Fung GL, Messig M, Laskey R. Systemic exposure to atorvastatin between Asian and Caucasian subjects: a combined analysis of 22 studies. Am J Ther. 2012;19:164-73.

33. Yang J, Li LJ, Wang K, He YC, Sheng YC, Xu L, et al. Race differences: modeling the pharmacodynamics of rosuvastatin in Western and Asian hypercholesterolemia patients. Acta Pharmacol Sin. 2011:32:116-25.

34. Lee E, Ryan S, Birmingham B, Zalikowski J, March R, Ambrose H, et al. Rosuvastatin pharmacokinetics and pharmacogenetics in white and Asian subjects residing in the same environment. Clin Pharmacol Ther. 2005;78:330-41.

35. Nakamura H, Arakawa K, Itakura H, Kitabatake A, Goto Y, Toyota T, et al. Primary prevention of cardiovascular disease with pravastatin in Japan (MEGA Study): a prospective randomised controlled trial. Lancet. 2006;368:1155-63.

36. Tirona RG. Ethnic differences in statin disposition. Clin Pharmacol Ther. 2005;78:311-6

37. Dohi T, Miyauchi K, Okazaki S, Yokoyama T, Yanagisawa N, Tamura H, et al. Early intensive statin treatment for six months improves long-term clinical outcomes in patients with acute coronary syndrome (Extended-ESTABLISH trial): a follow-up study. Atherosclerosis. 2010;210:497-502.

38. Miyauchi K, Daida H, Morimoto T, Hiro T, Kimura T, Nakagawa Y, et al. Reverse vessel remodeling but not coronary plaque regression could 
predict future cardiovascular events in ACS patients with intensive statin therapy-the extended JAPAN-ACS study. Circ J. 2012;76:825-32.

39. D'Ascenzo F, Agostoni P, Abbate A, Castagno D, Lipinski MJ, Vetrovec GW, et al. Atherosclerotic coronary plaque regression and the risk of adverse cardiovascular events: a meta-regression of randomized clinical trials. Atherosclerosis. 2013;226:178-85.

doi:10.1186/1471-2261-15-6

Cite this article as: Li et al.: The difference between Asian and Western

in the effect of LDL-C lowering therapy on coronary atherosclerotic

plaque: a meta-analysis report. BMC Cardiovascular Disorders 2015 15:6.

\section{Submit your next manuscript to BioMed Central} and take full advantage of:

- Convenient online submission

- Thorough peer review

- No space constraints or color figure charges

- Immediate publication on acceptance

- Inclusion in PubMed, CAS, Scopus and Google Scholar

- Research which is freely available for redistribution 